\title{
Planning of Urban Green Spaces: An Ecological Perspective on Human Benefits
}

\author{
Teodoro Semeraro $^{1} \mathbb{D}$, Aurelia Scarano ${ }^{2} \mathbb{D}$, Riccardo Buccolieri ${ }^{1, * \mathbb{D}}$, Angelo Santino ${ }^{2}$ and Eeva Aarrevaara ${ }^{3}$ \\ 1 Department of Environmental and Biological Sciences and Technologies, University of Salento, \\ S.P. 6 Lecce-Monteroni, 73100 Lecce, Italy; teodoro.semeraro@unisalento.it \\ 2 C.N.R. Unit of Lecce, Institute of Science of Food Production, 73100 Lecce, Italy; \\ aurelia.scarano@ispa.cnr.it (A.S.); angelo.santino@ispa.cnr.it (A.S.) \\ 3 Faculty of Technology, LAB University of Applied Sciences, Mukkulankatu 19, 15210 Lahti, Finland; \\ eeva.aarrevaara@lab.fi \\ * Correspondence: riccardo.buccolieri@unisalento.it; Tel.: +39-0832-297-062
}

check for updates

Citation: Semeraro, T.; Scarano, A.; Buccolieri, R.; Santino, A.; Aarrevaara, E. Planning of Urban Green Spaces: An Ecological Perspective on Human Benefits. Land 2021, 10, 105. https:// doi.org/10.3390/land10020105

Received: 23 November 2020

Accepted: 18 January 2021

Published: 22 January 2021

Publisher's Note: MDPI stays neutral with regard to jurisdictional claims in published maps and institutional affiliations.

Copyright: (c) 2021 by the authors. Licensee MDPI, Basel, Switzerland. This article is an open access article distributed under the terms and conditions of the Creative Commons Attribution (CC BY) license (https:// creativecommons.org/licenses/by/ $4.0 /)$

\begin{abstract}
In the context of urban land-use growth and the consequent impacts on the environment, green spaces provide ecosystem services for human health. The ecosystem services concept synthesises human-environmental interactions through a series of combined components of biodiversity and abiotic elements, linking ecological processes and functions. The concept of green infrastructure (GI) in the urban context emphasises the quality and quantity of urban and peri-urban green spaces and natural areas. In dense urban contexts, the applications of GI are limited and not applied to the potential urban spaces such as roofs and gardens. Often, roofs are characterised by impermeable paved surfaces with negative effects on human well-being, whereas garden designs do not consider social needs and environmental interactions. The role of urban stressors or the urban context as a driving force or pressure of urban green space is not always well understood and employed in the planning of green spaces. This is partly due to a knowledge gap between different science disciplines that operate on different scales, from single processes of the plants (which focus on plant responses to environmental stresses affecting human well-being) to urban ecosystems (which focus on the biodiversity and urban space planning-human well-being relationship). This can create a paradox, as green spaces that are not adequately designed might not produce the expected effects. In this paper, an overview of benefits and limitations of applying the ecosystem services approach when designing green spaces is presented. The focus is on the main urban ecosystem services provided by green roofs and community gardens such as GI that can represent strategies to provide ecological and social multifunctionality to waterproofed surfaces connected to the buildings and low-exploited gardens being the main areas that affect dense urban settlements, and thus, increasing the ecosystem services in the urban environment, such as reducing the Urban Heat Island, as well as flooding events. Specifically, the paper highlights (i) feedback between ecological processes and functions that support ecosystem services, (ii) urban environmental stresses in relation to disservices that these can create for human well-being and (iii) key issues that should be considered in the planning and design of urban ecosystem services. Such a new vision of urban ecosystem services highlights the need to look at GI as an active part of the urban space design in the built environment.
\end{abstract}

Keywords: urban green roofs; community gardens; ecosystem services and disservices; transdisciplinary approach; multifunctional land use

\section{Introduction}

Urban land use is the main cause of environmental impacts at both local and global scales [1]. Even though it represents only $2 \%$ of global land use, about half of the world's population lives in urban areas and most of the industrial activities are located here [1,2]. In 2019 , the urban population in the European Union was already $75 \%$ of the total population, while the ratio in North America was $80 \%$ and in Asia it was about $40 \%$ [3]. The number 
of cities with at least one million inhabitants will be almost duplicated until 2030: in 2000, the amount was 371 and it is predicted to rise to 706 in 2030 [4]. Approximately $90 \%$ of urban growth happens in developing countries, and Asia will have more than $60 \%$ of the urban population of the world by 2050. Additionally, the number of megacities (with over 10 million inhabitants) will grow, especially in Asia and Africa [5].

The use of green infrastructure (GI) is mainly based on the conditions that the city is experiencing: the size of the city, how fast it is growing, the economic situation and opportunities to support the green approach in urban renewal. In an ideal situation, GI has two different components, hubs and links, where the hubs are based on different kinds of green areas (for example public spaces, parks, forests etc.) and the links are the interconnections between the areas facilitating the flow of ecosystems, working as green corridors [6,7]. Another aspect is what kind of role urban GI has in urban planning; many rapidly growing cities are already lacking sufficient green spaces and infrastructure. Oijstaeijen et al. [8] claimed that the main reasons for not adapting urban GI in planning relate to a lack of knowledge regarding its costs, benefits and impacts [9].

One option to manage the lack of GI has been the launching of different systems to support a sufficient number of green areas, namely the Green Space Factor (GSF) or Biotope Area Factor (BAF) [10] or Green Index monitoring inspired by different models and organisations, such as the World Health Organisation (WHO) [11,12]. The development of green area factors started in the city of Berlin in 1984; since then, several greater cities have been adapting different models developed to meet their local needs.

Urban land-use may produce adverse effects on the land energy budgets and biogeochemical cycles. This is due to the capacity of the city to be a sink of carbon and nitrogen and to simultaneously increase their concentrations [13-15]. Activities carried out in urban areas emit carbon dioxide $\left(\mathrm{CO}_{2}\right)$, which is responsible for global climate change [16]. Furthermore, pollution has negative effects on human health at the local scale. Epidemiological studies have shown that increased concentrations of ozone $\left(\mathrm{O}_{3}\right)$ and particulate matter (PM) levels are associated with an increase in mortality due to respiratory and cardiovascular diseases $[17,18]$. Urbanisation, with the constructions of buildings, roads, squares, waste treatment etc., thus represents an important driving function of the weather and climate conditions $[1,19]$. Urban areas usually experience increased air and surface temperatures with respect to the surrounding rural area known as the Urban Heat Island (UHI) phenomenon $[20,21]$. The UHI increases with the growth of urban areas and industrialisation [22] as a direct consequence of structural and land cover changes from free space (natural or agricultural land) to the high density of urban structures, such as buildings, roads, paved squares etc. This is due to the increased heat-absorbing surface, the increase in heat production from anthropogenic sources, the stagnation of air, pollutants and heat and the reduction of vegetation evapotranspiration [17,23,24]. The main negative consequences of UHI include human discomfort and health, increased energy consumption during the summertime and impaired air and water quality $[17,25-29]$. The UHI also affects air quality because of the increasing energy consumption with elevated gas emissions. Moreover, high temperatures facilitate the formation of tropospheric $\mathrm{O}_{3}$, a harmful pollutant generated as nitrogen oxides react with volatile organic compounds (VOCs) during the daytime [30,31]. Finally, the growth of impervious surfaces, combined with an increase in the frequency and intensity of precipitation events, makes urban areas more vulnerable to flooding [32-36].

It is expected that the urban population will reach $70 \%$ of the total human population by 2050 [4]; therefore, this will produce an increase in urban areas with a potential increase in the demand for natural resources [37], particularly energy and water, with negative effects on human health [38]. It is, thus, necessary to develop models, strategies and policies of urbanisation that are able to increase the quality of human life in urban areas and mitigate the impact at both a local and global scale $[23,39,40]$. 


\section{Scope of the Paper}

Urban green spaces are widely recognised to mitigate the land use impact of urbanisation [41,42] and represent "publicly owned and accessible open spaces within urban and peri-urban areas that are wholly or partly covered by considerable amounts of vegetation" $[43,44]$. They include forests, road trees, trees in parks, gardens and nature conservation areas [45]. Parks, public gardens, road trees etc. are intrinsic elements in urban planning as there are specific indications in urban plans that regulate the relationship between green and built spaces [45]. The concept of ecosystem services synthesises humanenvironmental interactions that link biophysical structures and ecological functions with goods and services that are useful to humans [37,46,47] (Figure 1). The next aim is stimulating the creation of green spaces that are functional to the development of ecosystem services within the areas that are often designed in a monofunctional way, such as built spaces or grey infrastructures. For this purpose, it is important to understand the ecological functions that can be developed considering the integration of natural-based solutions in built environments or grey infrastructures, and the relative benefits or disservices that may derive from them, considering the interaction of the vegetation and context and their purpose.
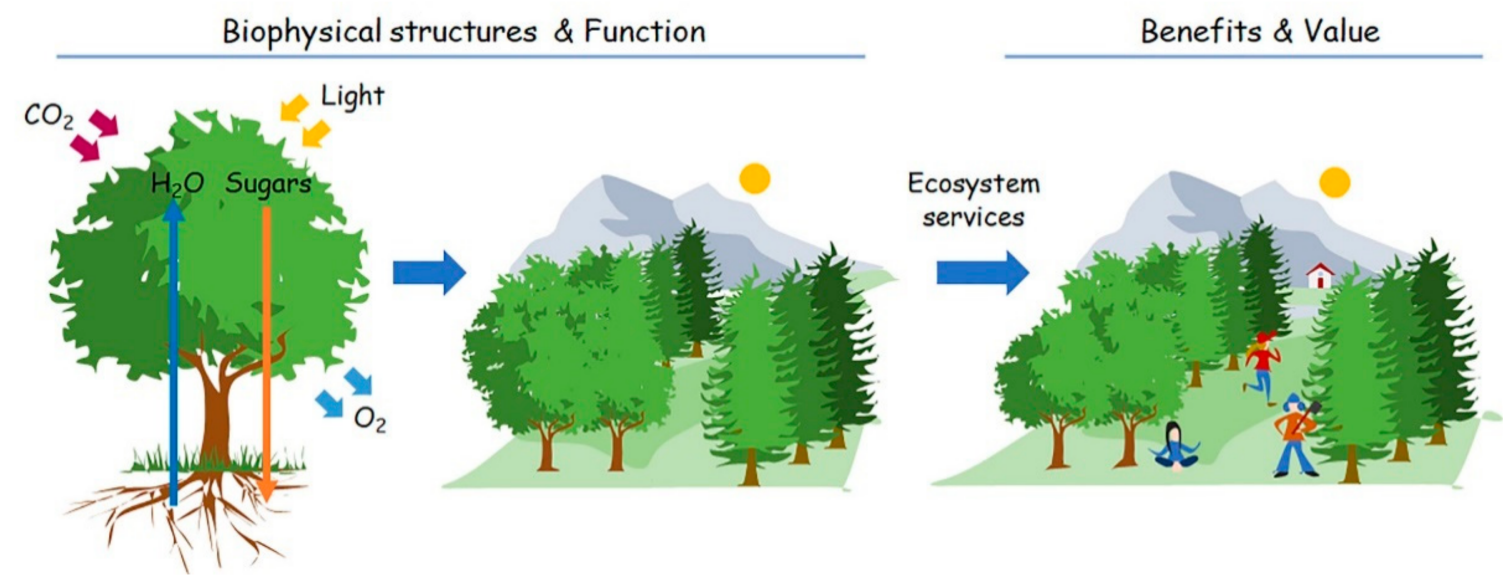

Figure 1. Schematic illustration of the concept of ecosystem services (inspired by de Groot et al. [46,47]), representing benefits and values for human well-being, deriving from plants and/or biophysical structures and functions implemented in green spaces.

In this context, the scope of this paper is to provide an overview of the benefits and limitations of applying an ecosystem services approach in designing GI, focusing on green roofs and community gardens. Many roofs are characterised by impermeable surfaces that have a direct effect on UHI, due to their vulnerability to flooding and energy consumption, and indirect effects on emission gases. The gardens of private and public spaces, such as closed gardens with ornamental vegetation, are often planned without considering the direct interaction between vegetation species, environmental matrix and social activities and needs. This produces a poor efficiency in the use of urban space [26-32]. Therefore, the integration of solutions with roofs and gardens can create GI which can represent strategies to provide ecological and social multifunctionality to waterproofed surfaces connected to the buildings and low-exploited gardens being the main areas that affect dense urban settlements. Therefore, stimulating an inclusive design of ecosystem services can help to increase the well-being of the population and reduce the negative impacts of urbanisation $[17,38]$.

Moreover, the role of urban stressors or the urban context as a driving force of urban GI is not always well understood and employed in the planning of green spaces. This is partly due to a knowledge gap between different science disciplines that operate on different scales, from single processes of the plants (which focus on plant responses to environmental stresses affecting human well-being) to urban ecosystems (which focus 
on the biodiversity and urban space planning-human well-being relationship). This can create a paradox, as green spaces that are not adequately designed might not produce the expected effects.

The design of green spaces to increase ecosystem services needs to adapt different scientific disciplines at different ecological and urban scales, such as single plant interactions with the surrounding environmental matrix, or the relationship of the vegetation with the municipality (macro-scale), neighbourhood (meso-scale) and individual buildings (micro-scale) $[40,45,48]$. Therefore, the green space has to be planned crossing various disciplines at a different survey scale to reduce the gap in the knowledge of single sectors or expertise.

Such an approach is based on a new transdisciplinary vision of urban ecosystem services that is not limited to the simple introduction of vegetation in urban areas but makes vegetation an active part of the urban space design, focusing on its effect on human well-being. Therefore, the intent here is to also provide a vision of the potential interactions between abiotic and biotic components that can affect individual plants in the urban context, as that can influence the ability of the vegetation to support the ecosystem services at different scales.

\section{Materials and Methods}

Following the illustration in Figure 1, a review has been carried out to identify the main ecosystem services supported by urban green spaces with a focus on green roofs and urban community gardens. The aim is to show a link between ecological functions, ecosystem services and benefits for human health. This can be useful in the ecological urban planning of green spaces, such as mitigation actions focused on introducing specific human benefits to reduce urban land use impacts.

The review was performed following the procedure suggested by Moher et al. [49]. Specifically, the initial identification was done by searching for articles using the Scopus, Web of Science and Science Direct platforms in addition to the articles known to the authors. The search was carried out in early 2020. The keywords searched were green infrastructure, ecosystem services, urban ecosystem services, green spaces, green roofs, urban garden, urban agriculture and community gardens. Moreover, to consider issues related to the connection between human health and not well-planned vegetation in urban areas, other keywords were used, such as environmental stressors, ecosystem disservices, vegetation stressors, abiotic stressors and secondary metabolites. Only papers written in the English language were considered. The screening of the outputs was manually performed to first remove duplicates, and then by checking the abstract, methodology and conclusions; only those fitting the topic of the paper were selected as eligible.

The analysis is presented in Section 3 (Results). First, a synthesis of the ecosystem services by urban green spaces is provided (Section 3.1), with a focus on green roofs (Section 3.2) and community gardens (Section 3.3). Ecosystem disservices related to the unsuitable use of vegetation are discussed in Section 3.4, providing examples related to pollution and to vegetation responses to environmental stressors. The Economics of Ecosystem and Biodiversity (TEEB) classification has been used to classify the services and is based on four categories: from 1 to 6 provisioning services; from 7 to 15 biological services; from 16 to 17 habitat services; and from 18 to 22 cultural and amenity services [46]. The final discussion is presented in Section 4, first focusing on the current use of green technologies in industrial areas with perspectives for an increasing use, and then providing planners with a framework tailored to the ecological planning of GI. Conclusions are given in Section 5.

\section{Results}

\subsection{Ecosystem Services Provided by Urban Green Spaces}

Table 1 summarises the main ecosystem services and related human benefits provided by urban green spaces. Specifically, urban green spaces reduce the heat-absorbing surface, 
increase solar protection, enhance cooling by shading and evapotranspiration (which help to mitigate the microclimate in the urban area), represent a sink for pollution, mask noise, filter out environmental pollutants by improving air quality and increase natural water retention $[23,36,50-53]$. Therefore, ecosystem services directly linked with urban green spaces are air filtration (gas regulation; carbon sequestration), micro-climate regulation, rainwater drainage (water regulation or stormwater management) and sewage treatment (waste treatment), the mitigation of disturbance regimes, with the increase of species diversity and composition, and cultural and educational values $[9,54-56]$.

Urban green spaces also decrease stress to visitors, increase property values and make urban areas more attractive [31]. The interactions of people with green spaces promote psychological wellness, improve mood and attention and reduce stress and anxiety [57-59]. Other services such as food production and erosion control could have lesser value in the urban context, but may be considered relevant in metropolitan or regional areas [55,60-62].

Positive effects of green space on the direct and indirect production of ecosystem services are still not well acknowledged [47] and new perspectives can be opened by the implementation of new technologies. For instance, dendrochemistry is a consolidated tool for detecting the release of contaminants from human activities over time and is applicable to tree sprawl that has been present for many years in the urban context, for example [89]. Consequently, the urban ecosystem characterised by trees can offer important spatial-temporal information that is classifiable as services and benefits (not included in the TEEB classification) that can be incorporated into urban planning processes [89-91].

Table 1. Example of the main ecosystem services provided by green spaces in urban areas considering the TEEB classification (from 1 to 6 provisioning services; from 7 to 15 biological services; from 16 to 17 habitat services; and from 18 to 22 cultural and amenity services), with selected references useful for a further reading. The table was structured following the ecosystem services classification and the link between ecological processes and benefits developed by de Groot et al. [46,63].

\begin{tabular}{|c|c|c|c|}
\hline Ecological Processes & Ecosystem Services & Benefits & $\begin{array}{c}\text { Selected } \\
\text { References }\end{array}$ \\
\hline $\begin{array}{l}\text { Energy flow from solar } \\
\text { radiation into edible } \\
\text { plants and animals }\end{array}$ & 1-Food & $\begin{array}{c}\text { Fruits } \\
\text { Small scale subsistence }\end{array}$ & {$[58,61,64-67]$} \\
\hline $\begin{array}{c}\text { Influences on material and } \\
\text { energy flow of the } \\
\text { ecosystem in } \\
\text { biogeochemical cycles } \\
\left(\mathrm{CO}_{2}, \text { ozone layer etc.) }\right.\end{array}$ & 7-Air quality regulation & $\begin{array}{l}\text { Reduction of the respiratory and } \\
\text { cardiovascular illnesses and allergies }\end{array}$ & $\begin{array}{c}{[9,17,18,31,44,58,} \\
67-75]\end{array}$ \\
\hline $\begin{array}{c}\text { Evapotranspiration } \\
\text { Increase of surface albedo }\end{array}$ & 8 -Climate regulation & $\begin{array}{l}\text { Increase of shade and thermal comfort } \\
\text { Reduction of heat-related illnesses } \\
\text { Reduction of greenhouse gas emissions }\end{array}$ & $\begin{array}{l}{[9,17,31,44,58,65,} \\
\quad 67,70,72-82]\end{array}$ \\
\hline \multirow[b]{2}{*}{ Flood prevention } & 11-Water treatment & \multirow{3}{*}{$\begin{array}{l}\text { Reduction of disturbance events } \\
\text { Increasing run-off volumes } \\
\text { Discharge rates }\end{array}$} & \multirow{3}{*}{$\begin{array}{c}{[9,17,36,44,58,65} \\
\quad 67,70,83,84]\end{array}$} \\
\hline & $\begin{array}{c}\text { 9-Moderation of disturbance } \\
\text { events }\end{array}$ & & \\
\hline $\begin{array}{l}\text { Filtering, retention and } \\
\text { storage water }\end{array}$ & 10-Water regulation & & \\
\hline $\begin{array}{l}\text { Accumulation of organic } \\
\text { matter }\end{array}$ & $\begin{array}{l}\text { 12-Erosion prevention } \\
\text { 13-Maintenance of soil } \\
\text { fertility }\end{array}$ & Maintenance of soil productivity & {$[44,58,65,75]$} \\
\hline $\begin{array}{l}\text { Living space suitable for } \\
\text { wild plants and animals' } \\
\text { growth and reproduction }\end{array}$ & $\begin{array}{c}\text { 14-Pollination } \\
\text { 15-Biological control } \\
\text { 16-Maintenance of life cycles } \\
\text { of migratory species } \\
\text { 17-Maintenance of genetic } \\
\text { diversity }\end{array}$ & Support biodiversity and genetic diversity & $\begin{array}{l}{[9,44,58,61,65-} \\
\quad 67,73]\end{array}$ \\
\hline
\end{tabular}


Table 1. Cont.

\begin{tabular}{|c|c|c|c|}
\hline Ecological Processes & Ecosystem Services & Benefits & $\begin{array}{c}\text { Selected } \\
\text { References }\end{array}$ \\
\hline $\begin{array}{c}\text { Attractive landscape } \\
\text { elements }\end{array}$ & 18-Aesthetic information & \multirow{5}{*}{$\begin{array}{c}\text { Promotion of green lifestyles } \\
\text { Increase of community engagement } \\
\text { Provision of recreational green spaces } \\
\text { Reduction of anxiety } \\
\text { Positive effect on behaviour } \\
\text { Attentional restoration } \\
\text { Reduction of mental fatigue } \\
\text { Improvement in cognitive functions, and } \\
\text { ability to perform tasks } \\
\text { Aesthetic appreciation } \\
\text { Increased inspiration } \\
\text { Increased recreational activities } \\
\text { Improve the quality of physical function } \\
\text { and/or health }\end{array}$} & \multirow{5}{*}{$\begin{array}{c}{[17,44,55,57,58,65-} \\
67,73,85-88]\end{array}$} \\
\hline $\begin{array}{l}\text { Diversity in the } \\
\text { recreational use of the } \\
\text { urban space }\end{array}$ & $\begin{array}{l}19-\text { Opportunities for } \\
\text { recreation and tourism }\end{array}$ & & \\
\hline $\begin{array}{c}\text { Diversity in the values of } \\
\text { cultural and artistic } \\
\text { natural elements }\end{array}$ & $\begin{array}{l}\text { 20-Inspiration for culture, } \\
\text { art, and design }\end{array}$ & & \\
\hline $\begin{array}{l}\text { Diversity in the values of } \\
\text { the spiritual and historic } \\
\text { natural elements }\end{array}$ & 21-Spiritual experience & & \\
\hline $\begin{array}{l}\text { Diversity in the values of } \\
\text { nature with scientific and } \\
\text { educational implications }\end{array}$ & $\begin{array}{c}\text { 22-Information for cognitive } \\
\text { development }\end{array}$ & & \\
\hline
\end{tabular}

However, the provision of ecosystem services in public urban spaces is not sufficient to guarantee the quality of human life in growing cities. Private actions in private space need to take social responsibility; for example, by developing urban elements integrating functional biodiversity that is able to support ecosystem services to reduce the environmental impacts and increase human well-being $[2,56,92,93]$. It is important to apply multifunctional land use actions to guarantee the simultaneous use of space for human activities such as housing, and ecosystem services production such as stormwater retention, energy conversion and habitat creation, involving both the public and private sectors [94].

Private actions are, among others, related to green roofs development and agricultural urban community gardens, as discussed in the following subsections (Sections 3.2 and 3.3).

\subsection{Green Roofs}

Green roofs represent a strategy to transform the sealed and solar radiation heat surfaces of a rooftop into multifunctional ecological spaces [94]. In general, a green roof consists of vegetation, growth medium (substrate) and many other layers (drainage layer, waterproofing membrane etc.) to prevent negative effects of the interaction between vegetation and building structures and the healthiness of the building $[95,96]$. Considering the thickness of the substrate and the type of vegetation that it can sustain, green roofs are classified as follows [96]:

- "Extensive green roof" with a substrate thickness lower than $15 \mathrm{~cm}$ and a weight of up to $100 \mathrm{~kg} / \mathrm{m}^{2}$. It can be "single-course extensive", with a thickness of $10 \mathrm{~cm}$ and characterised mainly by grass vegetation, or "multi-course extensive", with a thickness of $15 \mathrm{~cm}$ and characterised by a mix of grass and shrubs;

- "Intensive green roof", with a thickness larger than $15 \mathrm{~cm}$ and an average weight of up to $1000 \mathrm{~kg} / \mathrm{m}^{2}$. It can be distinguished into "semi-intensive", with a thickness from $20 \mathrm{~cm}$ to $30 \mathrm{~cm}$, and "intensive", with a thickness larger than $30 \mathrm{~cm}$.

The first type can support grass and shrubs, whereas the second can support shrubs and low trees [94,97-99].

Green roofs are natural-based solutions used in public and private buildings to increase ecosystem services with positive effects on energy consumption, urban heat island impacts and greenhouse gas generation in urban areas [56,100]. Table 2 summarises the main ecosystem services and the related human benefits they provide.

The intensive green roof can produce more ecosystem services and better sustain human health in the city with respect to extensive ones, emphasising the use of public spaces and raising aesthetic expectations. However, it needs more building structural 
support, with costs related to its realisation and maintenance [94,96,101]. On the other hand, the extensive green roof presents less weight, does not require irrigation and has lower capital and maintenance costs; therefore, this is the most commonly used [23,101,102]. It has also been proven to be effective in mitigating floods. Indeed, it was estimated that it has the capacity to reduce the stormwater volume from $50 \%$ to $60 \%$ of total annual precipitation $[103,104]$.

Table 2. Ecosystem services and main environmental benefits provided by green roofs, with selected references useful for a further reading. See Table 1 for details.

\begin{tabular}{|c|c|c|c|}
\hline Ecological Processes & Ecosystem Services & Benefits & $\begin{array}{c}\text { Selected } \\
\text { References }\end{array}$ \\
\hline $\begin{array}{l}\text { Energy flow from solar } \\
\text { radiation into edible plants } \\
\text { and animals }\end{array}$ & 1-Food & $\begin{array}{c}\text { Fruits } \\
\text { Small-scale subsistence }\end{array}$ & {$[23,101,105-111]$} \\
\hline $\begin{array}{l}\text { Influences on material and } \\
\text { energy flow of the ecosystem } \\
\text { in biogeochemical cycles } \\
\left(\mathrm{CO}_{2} \text {, ozone layer etc. }\right)\end{array}$ & 7-Air quality regulation & $\begin{array}{c}\text { Evacuation of air pollutants such as } \\
\text { particulate matter, carbon dioxide, } \\
\text { nitrogen dioxide, carbon monoxide and } \\
\text { sulphur dioxide } \\
\text { Carbon sink } \\
\text { Reduction of carbon footprints }\end{array}$ & $\begin{array}{c}{[65,96,101,110,112-} \\
114]\end{array}$ \\
\hline Increase of surface albedo & 8-Climate regulation & $\begin{array}{l}\text { Mitigation of heat flux into the building } \\
\text { Reduction of energy demand for space } \\
\text { climate conditioning } \\
\text { Mitigations of the urban heat island effect } \\
\text { Increase of thermal comfort } \\
\text { Reduction of urban energy consumption } \\
\text { Reduction of carbon footprints } \\
\text { Decrease of cooling and heating }\end{array}$ & {$[65,94,101,110-119]$} \\
\hline \multirow[t]{2}{*}{$\begin{array}{l}\text { Flood prevention } \\
\text { Filtering, retention and } \\
\text { storage water }\end{array}$} & $\begin{array}{c}\text { 11-Water treatment } \\
\text { 9-Moderation of disturbance } \\
\text { events }\end{array}$ & \multirow[t]{2}{*}{$\begin{array}{l}\text { Reduction of stormwater volume } \\
\text { Decrease of the burden of the water } \\
\text { treatment facilities } \\
\text { Improvement of rainwater use }\end{array}$} & \multirow[t]{2}{*}{$\begin{array}{c}{[23,65,94,101,103,} \\
104,110-112,120- \\
122]\end{array}$} \\
\hline & 10-Regulation of water flows & & \\
\hline $\begin{array}{l}\text { Living space suitable for wild } \\
\text { plants and animals' growth } \\
\text { and reproduction }\end{array}$ & $\begin{array}{c}\text { 14-Pollination } \\
\text { 15-Biological control } \\
\text { 16-Maintenance of life cycles } \\
\text { of migratory species } \\
\text { 17-Maintenance of genetic } \\
\text { diversity }\end{array}$ & $\begin{array}{l}\text { Provision of habitat for insect and } \\
\text { animals } \\
\text { Implementation of vegetation } \\
\text { biodiversity and improved landscape }\end{array}$ & $\begin{array}{c}{[65,94,101,110-} \\
113,123-125]\end{array}$ \\
\hline Attractive landscape features & 18-Aesthetic information & \multirow{5}{*}{$\begin{array}{l}\text { Relaxation and recreation } \\
\text { Provision of recreational space } \\
\text { Decrease of the noise pollution }\end{array}$} & \multirow{5}{*}{$\begin{array}{l}{[65,87,101,110-} \\
\quad 112,126]\end{array}$} \\
\hline $\begin{array}{l}\text { Diversity in the recreational } \\
\text { use of the urban space }\end{array}$ & $\begin{array}{l}\text { 19-Opportunities for } \\
\text { recreation and tourism }\end{array}$ & & \\
\hline $\begin{array}{l}\text { Diversity in the values of } \\
\text { cultural and artistic natural } \\
\text { elements }\end{array}$ & $\begin{array}{l}\text { 20-Inspiration for culture, art } \\
\text { and design }\end{array}$ & & \\
\hline $\begin{array}{l}\text { Diversity in the values of the } \\
\text { spiritual and historic natural } \\
\text { elements }\end{array}$ & 21-Spiritual experience & & \\
\hline $\begin{array}{l}\text { Diversity in the values of } \\
\text { nature with scientific and } \\
\text { educational implications }\end{array}$ & $\begin{array}{c}\text { 22-Information for cognitive } \\
\text { development }\end{array}$ & & \\
\hline
\end{tabular}

Introducing vegetation onto the roof may help to increase biodiversity in urban areas. However, since green roofs are artificially created habitats with different environmental conditions with respect to natural conditions, such as high radiation and temperature, 
the use of autochthonous vegetation may be difficult to apply and not always feasible. Therefore, the use of green roofs has to disregard conservation actions that require the use of local vegetation because it could make this strategy ineffective and expensive. Different vegetation can be planned: officinal plants, aromatic plants, fruits etc. with the idea to create widespread urban gardens. This could be a characterising element of a neighbourhood and a point of attraction. In this perspective, green roofs could become enjoyable areas for social activities [56].

The green roof can mix built and green areas and the multifunctionality, in this case, represents the capacity to produce a stratified use of the urban space passing from the mono-functional use of specific urban space into integrating different functionalities that are capable of increasing ecological and social human well-being (an example is provided in Figure 2). However, to incorporate green roof technology into urban strategies around the world, it is crucial to develop solutions that are able to reduce the costs of installation considering the roof weight limitations and appropriate management practices [109].
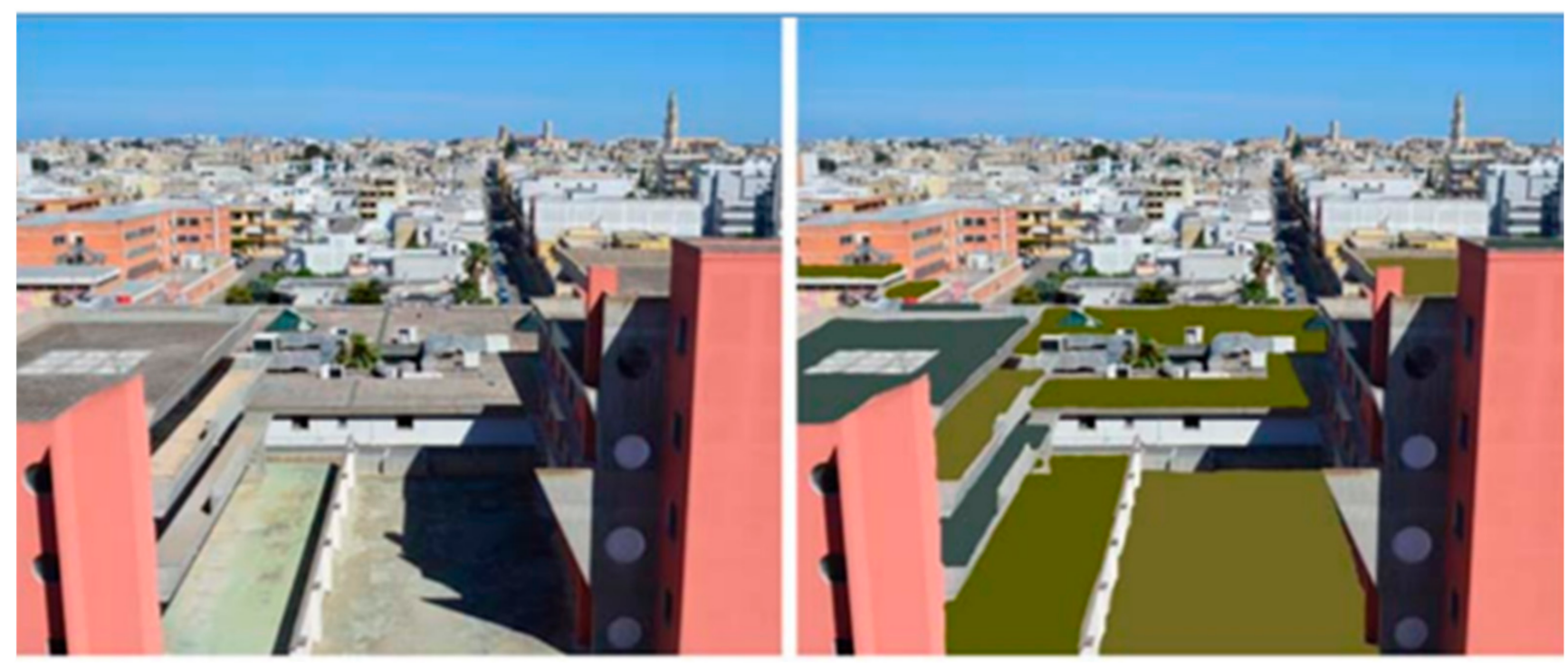

Figure 2. Example of overbuilding (left) which would benefit from strategies using green roofs (right).

\section{New Frontiers of Green Roofs}

Recently, hybrid photovoltaic (PV) green roofs have been proposed as a new perspective of the natural-based solution in the green roof industry, since they enhance the electrical yield $[101,127]$. The vegetation can reduce the surrounding temperature of PV panels, while at the same time being less exposed to the sun by PV panels. The increase in the energy efficiency of PV green roofs has been estimated to range from 1.3\% to $8.3 \%$ compared to the traditional installation of PV systems [128-130].

In this perspective, an important example is represented by the solution introduced from the Korea Institute of Civil Engineering and Building Technology. It developed a "green-blue roof" that provides the possibility to introduce a green area and water storage in the roof in one solution. The roof is characterised by a vegetation layer on the water layer. This solution can store more water, decreasing the runoff and avoiding flash flooding effects, and can store the water that can be employed for domestic use [131,132].

The recent project idea proposed by Semeraro et al. [56], starting from the surface of the existing roof-top, suggested the possibility of designing a green roof, such as a phytodepuration system, for the grey water for a building with 26 flats. The idea started from the consideration that using the roof space to introduce the photovoltaic system is not sufficient to meet the energy needs for each apartment. On the other hand, the surface of the building is sufficient to create an engineered habitat provisioning ecosystem services, such as water treatment for the reuse of grey water in the building. The use of recycled 
water, for example for the toilet flush, can save 35\% of clear water, as well as the benefits reported in Table 2. This can reduce the use of clear water in those geographical regions with a scarcity of water, mainly in the summer. The main differences from the green-blue roof and the green roof for water treatment are in the choice of vegetation, in the latter case with selected vegetation that is able to support the phytoremediation.

These extreme solutions can be reconsidered when analysing natural resource availability in the future. For instance, the World Resources Institute estimated that there will be a reduction in water availability for human use in many parts of the world by 2050 [133]. These events have not happened to date, although the first real water crisis occurred in Cape Town between 2017 and 2018, when the population lived on 50 litres of water per day; the inhabitants were forced to adapt their daily habits, and the main security problem was water theft.

\subsection{Community Gardens}

The concept of urban community gardens is generally linked to the practice of growing crops in urban and peri-urban areas [134-136]. It provides food products, as well as aromatic and medicinal herbs, ornamental plants etc. [134]. Urban agriculture does not have a fixed dimension or preferable urban space but can be performed in any shape and in different places, such as brownfield sites, roofs, greenfield sites (i.e., parks, gardens) etc. $[137,138]$. In the urban context, agriculture can represent a multifunctional land-use strategy [139], because it can integrate agriculture activities with social and ecological function purposes [140].

In the context of biodiversity loss, food insecurity and social alienation due to urbanisation, urban community gardens can represent sites for urban residents to reconnect with nature in a social environment creating common spaces and new forms of community interaction and corporations $[137,141]$. Ecosystem services and related benefits for human well-being are summarised in Table 3.

Specifically, urban community gardens contribute to ecological sustainability by providing agroecosystems that can improve soil quality and reduce soil erosion rainwater runoff [142-144]. They can also impact on climate change/urban microclimates and stimulate the productive reuse of urban organic waste, thus reducing the urban resource footprint [145]. The social and economic goods and benefits of community gardens include increasing access to fresh fruits and vegetables, building community ties and community economic revitalisation, and regenerating vacant, neglected, or disturbed urban spaces. The community gardens are useful for promoting a sense of individual well-being and health in urban areas where there is social isolation and cultural diversity, promoting cross-cultural communication. Moreover, community gardens can improve cultural and educational ecosystem services by connecting people to the cycles of the earth, biodiversity and natural processes and improving people's practical gardening skills [146-149].

Community gardens can reinforce people's relations using food production, such as the urban activity of social and cultural connections, by bringing together diverse groups of people, stimulating the sharing of agricultural and culinary knowledge, and creating stronger bonds in the community [150]. Community gardens are also considered "participatory landscapes" of resistance to racism and marginalization through collective work and self-reliance [151-153]. 
Table 3. Ecosystem services and main environmental benefits provided by urban community gardens, with selected references useful for a further reading. See Table 1 for details.

\begin{tabular}{|c|c|c|c|}
\hline Ecological Processes & Ecosystem Services & Benefits & Selected References \\
\hline $\begin{array}{l}\text { Energy flow from solar } \\
\text { radiation into edible plants } \\
\text { and animals }\end{array}$ & 1-Food & $\begin{array}{l}\text { Fruits } \\
\text { Small-scale subsistence } \\
\text { Food security } \\
\text { Raising awareness of the inhabitants } \\
\text { Food production and processing } \\
\text { Energy consumption and production }\end{array}$ & $\begin{array}{c}{[137,139,141,144,148,} \\
154-164]\end{array}$ \\
\hline
\end{tabular}

\begin{abstract}
Influences on Material and energy flow of the ecosystem in biogeochemical cycles $\left(\mathrm{CO}_{2}\right.$, ozone layer etc.)
\end{abstract}

Evacuation of air pollutants such as particulate matter, carbon dioxide, nitrogen dioxide, carbon monoxide and sulphur dioxide Carbon sink

$[139,142-$

$145,158,163,165,166]$

Reduction of carbon footprints

Evapotranspiration 8-Climate
regulation

Increase of surface albedo

the urban heat island effect Increase of thermal comfort

Reduction of urban energy consumption

Reduction of carbon footprints linked to the food

Decrease of cooling and heating loads

Reduction of gas emissions for food supplying

\begin{tabular}{|c|c|c|c|}
\hline \multirow{3}{*}{$\begin{array}{l}\text { Flood prevention } \\
\text { Filtering, retention and } \\
\text { storage water }\end{array}$} & & \multirow{3}{*}{$\begin{array}{l}\text { Reduction in stormwater volume } \\
\text { Stormwater retention }\end{array}$} & \multirow{3}{*}[65,144,165]{} \\
\hline & $\begin{array}{l}\text { 9-Moderation of } \\
\text { extreme events }\end{array}$ & & \\
\hline & $\begin{array}{l}\text { 10-Regulation of } \\
\text { water flows }\end{array}$ & & \\
\hline $\begin{array}{l}\text { Accumulation of organic } \\
\text { matter }\end{array}$ & $\begin{array}{l}\text { 12-Erosion } \\
\text { prevention } \\
\text { 13-Maintenance of } \\
\text { soil fertility }\end{array}$ & $\begin{array}{l}\text { Retention of soil nutrients } \\
\text { Organic waste and production of compost }\end{array}$ & {$[65,139,158,163,164]$} \\
\hline $\begin{array}{l}\text { Living space suitable for wild } \\
\text { plants and animals' growth } \\
\text { and reproduction }\end{array}$ & $\begin{array}{l}\text { 14-Pollination } \\
\text { 15-Biological } \\
\text { 16-Maintenance of } \\
\text { life cycles of } \\
\text { migratory species } \\
\text { 17-Maintenance of } \\
\text { genetic diversity }\end{array}$ & $\begin{array}{c}\text { Provision of habitat for insect and animals } \\
\text { Implementation of vegetation biodiversity } \\
\text { Improvement of landscape agrobiodiversity of } \\
\text { plants grown }\end{array}$ & $\begin{array}{l}{[65,139,141,154,155,} \\
157-159,162,163,165]\end{array}$ \\
\hline Attractive landscape features & $\begin{array}{l}\text { 18-Aesthetic } \\
\text { information }\end{array}$ & \multirow{5}{*}{$\begin{array}{c}\text { Relaxation and recreation } \\
\text { Provision of recreational space with safety and } \\
\text { security perception } \\
\text { Horticultural practices and maintenance } \\
\text { Community support, funding and volunteer } \\
\text { management } \\
\text { Cultivating psychological well-being } \\
\text { Constructing Community } \\
\text { Building social bonds } \\
\text { Breaking down social barriers } \\
\text { Cleaning up vacant lots } \\
\text { Reclaiming the city } \\
\text { Cultural identity }\end{array}$} & \multirow{5}{*}{$\begin{array}{c}{[65,137-} \\
139,141,144,154- \\
156,158-160,162- \\
164,167]\end{array}$} \\
\hline $\begin{array}{l}\text { Diversity in the recreational } \\
\text { use of the urban space }\end{array}$ & $\begin{array}{l}\text { 19-Opportunities } \\
\text { for recreation and } \\
\text { tourism }\end{array}$ & & \\
\hline $\begin{array}{l}\text { Diversity in the values of } \\
\text { cultural and artistic natural } \\
\text { elements }\end{array}$ & $\begin{array}{l}\text { 20-Inspiration for } \\
\text { culture, art and } \\
\text { design }\end{array}$ & & \\
\hline $\begin{array}{l}\text { Diversity in the values of the } \\
\text { spiritual and historic natural } \\
\text { elements }\end{array}$ & $\begin{array}{l}\text { 21-Spiritual } \\
\text { experience }\end{array}$ & & \\
\hline $\begin{array}{l}\text { Diversity in the values of } \\
\text { nature with scientific and } \\
\text { educational implications }\end{array}$ & $\begin{array}{l}\text { 22-Information for } \\
\text { cognitive } \\
\text { development }\end{array}$ & & \\
\hline
\end{tabular}




\section{New Frontiers for Urban Community Gardens}

The new frontiers for urban community gardens are to combine food and urban design to produce material pushed from strong synergies between waste production in the building and the capacity of urban community gardens to recycle urban waste, such as organic matter, wastewater and waste heat [141]. This combination can develop an urban system that is able to reuse residential or industrial waste resources with benefits including food production for local consumption and the reduction of the consumption of natural resources [164]. This strategy can be achieved by creating a low or even "no-input system" around a sustainable food infrastructure $[168,169]$ that produces a "closed-loop entity" in terms of waste recycling that is able to reduce pollution [164]. The connection of urban needs, ecological and productive activities at the scale of the building is a strong ambition that can support the sustainability of the cities, reducing the environmental impacts generated by urban waste $[164,170,171]$.

Urban community gardens could also be used as a strategy to provide a temporary new functionality to spaces which are no longer able to meet current social and economic needs (those areas are often fenced and prey to devastation and misuse, such as illegal housing and drug dealing). For instance, in Baltimore, the urban community gardens began as vacant spaces that were considered "crime-ridden eyesores". Residents worked together to change the status of the neighbourhoods, transforming these abandoned spaces into community gardens, clearing the lots of rubble, mowing the weeds and eliminating trash and drugs. The residents stated that community gardens made their neighbourhoods safer and more stable [162].

\subsection{Counterbalancing Ecosystem Disservices}

Urban ecosystems can support functions with negative effects for human well-being called ecosystem disservices [172,173] (some of those are summarised in Table 4). For example, trees can cause problems such as allergies generated by pollens, leaves blocking stormwater drains, roots cracking pavements, trees falling along avenues, causing material damage to things and people, and residents' fearing increased crime [174,175]. These can produce several urban issues related to safety and security, health, mobility and the environment [176]. Specifically, green roofs and urban community gardens can have negative effects on human health, therefore creating ecosystem disservices if they are not adequately designed. For example, in urban areas nitrogen, phosphorus, potassium and other nutrients may accumulate in garden soils [177] due to the indiscriminate application of fertilisers, polluting urban stormwater runoff or the emission of exhaust gases of different natures [141].

The distinction between ecosystem services and disservices is not absolute, but highly dependent on the combination of ecological processes that characterise the vegetation, the purpose of the green spaces and the application of the ecosystem services design. Moreover, ecosystem services may be affected by several factors, such as age, education, cultural values, attitudes, health conditions, knowledge of the person making the evaluation and context of reference [178]. Therefore, a choice of plant species that does not consider the context and the stakeholders involved could produce unintentional results.

For example, hemp can be used in agricultural activities to produce raw materials for different uses, therapeutic oils etc. Hemp also has a high capacity to absorb heavy metals from the soil. The absorption of soil and air pollutants represents an ecosystem service, since the ability of some plant species-including edible species-to efficiently absorb and accumulate pollutants such as heavy metals can be successfully applicable in planning specific green urban areas for phytoremediation [179-181]. However, for agricultural purposes, the absorption of heavy metals can be considered a disservice because it could lead to unusable products if they have high concentrations of metals [182]. 
Table 4. Examples of disservices provided by urban GI (modified from Gómez-Baggethun and Barton [173] and von Döhren and Haase, [183]), with selected references useful for a further reading.

\begin{tabular}{|c|c|c|c|}
\hline Ecosystem Functions & Disservices & Examples & Selected References \\
\hline Photosynthesis & $\begin{array}{l}\text { Air quality } \\
\text { problems }\end{array}$ & $\begin{array}{c}\text { Emission of the volatile } \\
\text { organic compounds (VOCs) } \\
\text { Concentrations of particulate } \\
\text { matter (PM) }\end{array}$ & [184-188] \\
\hline Vegetation biomass growth & Blockage of landscape view & $\begin{array}{l}\text { Limit of the scenic views by } \\
\text { trees located in front of the } \\
\text { windows of the buildings }\end{array}$ & [189] \\
\hline $\begin{array}{c}\text { Flow of floral } \\
\text { gametes such as pollen }\end{array}$ & Allergies and/or intoxication & Allergic reactions & {$[50,73,172,187,190-192]$} \\
\hline Plants aging & Accidents & $\begin{array}{l}\text { Break up of trees and branches } \\
\text { falling in roads causing } \\
\text { damage of matter and people }\end{array}$ & [189] \\
\hline $\begin{array}{l}\text { Dense development of the } \\
\text { plants }\end{array}$ & Fear and stress & $\begin{array}{c}\text { Dark green areas perceived } \\
\text { unsafe }\end{array}$ & {$[193,194]$} \\
\hline $\begin{array}{l}\text { Decomposition and biomass } \\
\text { root fixation }\end{array}$ & Damages to infrastructure & Breaking up of pavements & {$[73,172]$} \\
\hline
\end{tabular}

\begin{tabular}{|c|c|c|c|}
\hline $\begin{array}{l}\text { Habitat provision for animal } \\
\text { species }\end{array}$ & $\begin{array}{c}\text { Habitat competition with } \\
\text { humans } \\
\text { Abundance of undesired } \\
\text { species Introduction of } \\
\text { invasive species } \\
\text { Contamination of crops with } \\
\text { pathogenic organisms or } \\
\text { residues of } \\
\text { agrochemicals and other } \\
\text { pollutants through } \\
\text { contaminated soil, water } \\
\text { or air }\end{array}$ & $\begin{array}{l}\text { Animals/insects perceived as } \\
\text { scary, unpleasant and/or } \\
\text { disgusting } \\
\text { Animal species can be vectors } \\
\text { of diseases (e.g., avian } \\
\text { influenza, rabies) } \\
\text { Population development of } \\
\text { invasive species }\end{array}$ & {$[73,134,140,193,195-197]$} \\
\hline Water supply & $\begin{array}{c}\text { Decrease in water } \\
\text { quality/quantity } \\
\text { inappropriate drawing of } \\
\text { water sources threat of local } \\
\text { water sources or underground } \\
\text { water contamination } \\
\text { due to uncontrolled treatment } \\
\text { of fertilisers, pesticides or rich } \\
\text { manure } \\
\text { from animals }\end{array}$ & $\begin{array}{l}\text { Amount of water used for } \\
\text { plant growth } \\
\text { Water pollution }\end{array}$ & $\begin{array}{c}{[50,134,140,141,177,187,192,} \\
195-198]\end{array}$ \\
\hline Soil erosion & $\begin{array}{l}\text { Poor environmental } \\
\text { conditions of land, further } \\
\text { depletion of soil quality }\end{array}$ & $\begin{array}{l}\text { Use of fertilisers that can alter } \\
\text { the quality of the soil }\end{array}$ & {$[135,140,195,197]$} \\
\hline
\end{tabular}

\section{Planning Community Gardens to Avoid Disservices}

The benefits of urban community gardens are mainly limited to crop species with both compact growth and rapid cycling [198,199]. Generally, the horticultural species suggested for urban community gardens are lettuce and leafy green vegetables. Other vegetables of eligibility are carrots, zucchini, peppers, tomatoes and onions, but other species can be chosen based on specific secondary metabolites that are important for human health [200,201]. Plant sources of carbohydrates (e.g., potatoes) and proteins (e.g., legumes) can also be included in planning urban gardens. In planning urban gardens, a balance of pros and cons should be considered (e.g., the cultivated vegetables should be safe and nutritious). The main factors impacting on the agricultural urban space design are: 
exposure to pollutants (type, concentration, distance from the source, length of exposure), meteorological conditions, plant species with reduced capacity of accumulation of toxic substances and soil properties (Figure 3). For example, the exposure to pollutants such as $\mathrm{SO}_{2}$ (sulphur dioxide), $\mathrm{NOx}$ (nitrogen oxides such as nitrite, nitrate etc.) or a variety of hydrocarbons can cause accumulation as surface deposits either in the soil or on the leafy parts of plants. Exposed leaves start to lose their colour and turn brown; eventually, plant growth will be severely impaired.

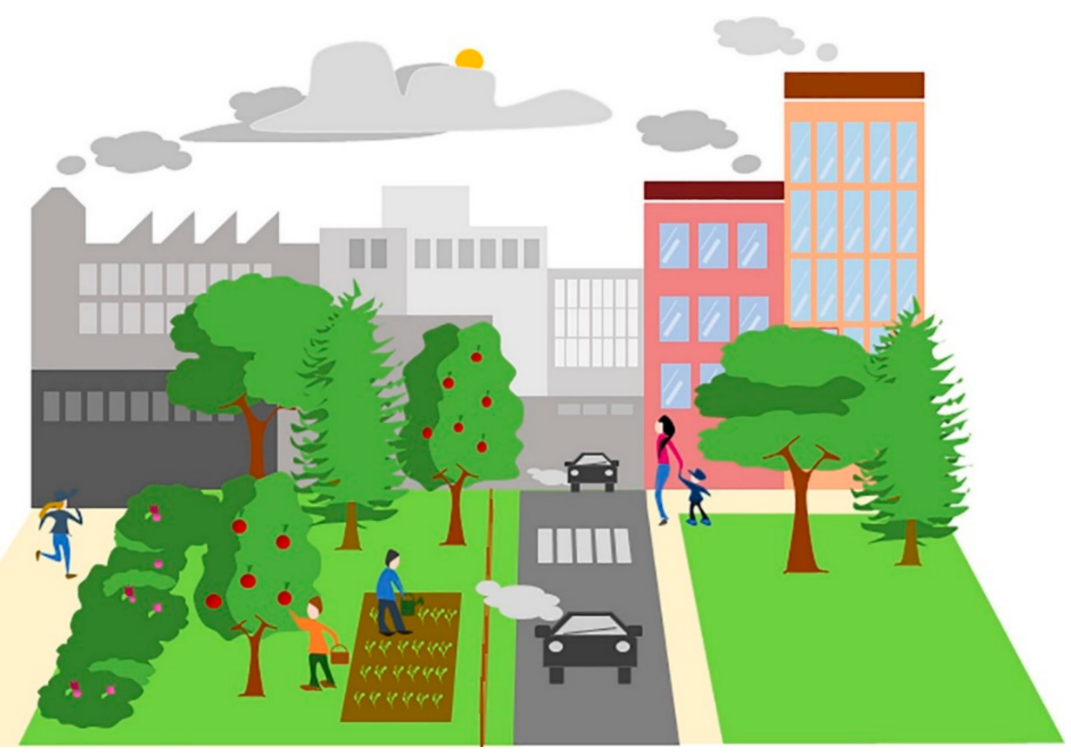

Figure 3. Representation of pollution stress for the vegetation employed in urban community gardens. An inadequate design of GI can influence the quality of urban green spaces due to the presence/production of environmental stressors and the related capacity to provide ecosystem services.

Furthermore, excessive lead $(\mathrm{Pb})$ accumulation in plant tissues severely impacts important physiological and biochemical functions, resulting in altered uptake of microelements, and stomatal closure inducing a deficient $\mathrm{CO}_{2}$ uptake. Leafy, tuberous vegetables and beans tend to accumulate higher concentrations of lead than cereals and fruit crops such as tomatoes [202,203]. For example, Zhou et al. [204] investigated the heavy metal accumulation in different vegetable species to assess the human health risks derived from the consumption of these vegetables. The highest concentration of heavy metals was reported in leafy vegetables, more than stalk vegetables, root vegetables, solanaceous species and legumes, whereas the lowest accumulator was melon, indicating that these species are more suitable for cultivation on urban soil.

Some ecosystem disservices can be due to the interaction of plant-environmental stressors (Figure 3). In fact, the exposure to environmental and/or abiotic stresses is an important stimulus to produce a number of "chemical responses" in plants, which are the direct biochemical products of their metabolism. Examples of metabolites produced by plants as a defence response with protective and ecological functions, but potentially toxic or anti-nutrient for animals and humans, are some alkaloids, cyanogenic glucosides or some organic acids such as oxalates [205-208]. For example, cyanogenic glucosides are chemical compounds produced by plants for self-defence from stressors, whose ingestion in high amounts can cause intoxication in animals and humans [207]. However, they are normally found in several plants, most of them with edible parts, such as almonds, apples, apricot, plums and peaches, particularly in the seeds of such fruits. The cyanogenic glucosides can be produced following nitrogen supply of soil (i.e., with nitrogenous fertilisers) and stressful growth conditions induced by environmental factors, such as light, temperature and drought [208]. Therefore, it would be important to exclude the use of 
edible plants that are strongly affected by this interaction in common gardens in very polluted neighbourhoods or streets.

Therefore, ecosystem disservices due to the interaction of plant-environmental stressors can create a paradox, because if green spaces are not adequately designed in relation to the context, they can also have negative effects on the quality of the green space and the capacity to produce services.

\section{Discussion}

An analysis of the existing literature highlights that green roofs and community gardens are a good strategy for developing ecosystem services such as air quality and climate regulation, the mitigation of extreme events and regulation of water flows, thus reducing the negative impacts produced by the impervious surfaces that mainly causes UHI and flooding events. Green roofs and community gardens can also promote vegetation biodiversity, create biodiversity connections between habitats for insects and animals (Figure 4), improve mental and physical health etc. In growing cities, where there is the presence of different cultures, community gardens seem to provide an important contribution to the reduction of racism and social problems.
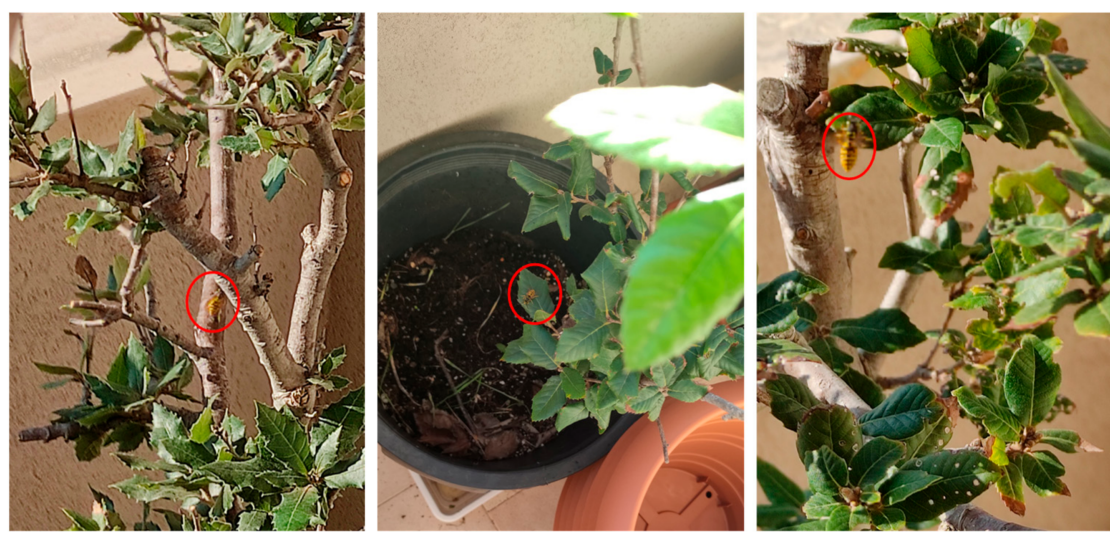

Figure 4. Example of how simple holm oak plants positioned on the balcony can be used by bees for foraging.

However, the design of GI must also consider appropriate plants based on the purpose to be achieved and the problem to be addressed, as well as the energy and material flow that can arise between plants and the surrounding environment. Such energy and material flows characterise the ecological functions that are the basis of ecosystem services and disservices which may produce benefits or negative effects on human well-being, respectively. In this sense, vegetation should not be considered a simple element of street furniture but as an element interacting with the environment.

Currently, the application of green roofs and community gardens is sporadic and often linked to single buildings and private actions. There are some examples around the world of the applications combining green roofs and community gardens with grey infrastructures or examples linked with specific social and economic activities (https:/ /www.greenme.it/ abitare/bioedilizia-e-bioarchitettura/tetti-verdi-nel-mondo-green-roof/) (Figure 5).

Despite the consolidated scientific knowledge on the enormous benefits that GI can produce if appropriately designed, in rapidly growing cities, planners and decision-makers do not pay enough attention to its development. For example, the industrial sector still has a poor appreciation of the benefits of green technologies $[25,99]$. The industrial area represents a built environment located on the boundary of cities or, in some cases, absorbed by cities, and represents a big impermeabilisation of the urban surface compared to the dimension of cities. Figure 4 shows that such areas present few green areas in many cities. As for green roof technologies, the industrial sector is probably scared off by the initial cost 
of installation compared to the standard roof construction, not considering the long-term benefits in saving energy and management cost [209].

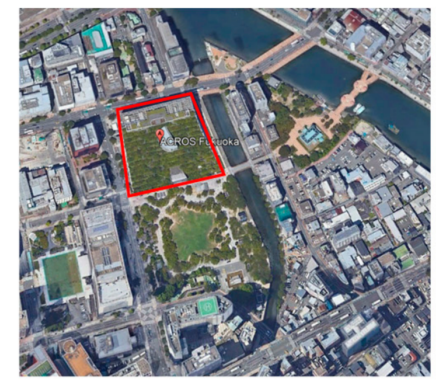

ACROS Fukuoka - Japan

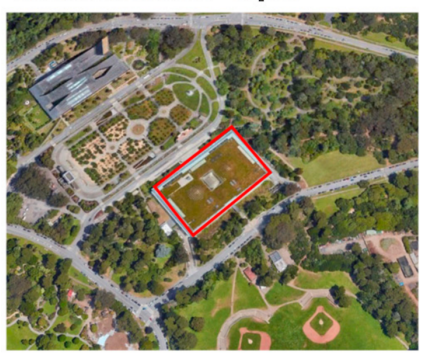

Academy of Sciences - California

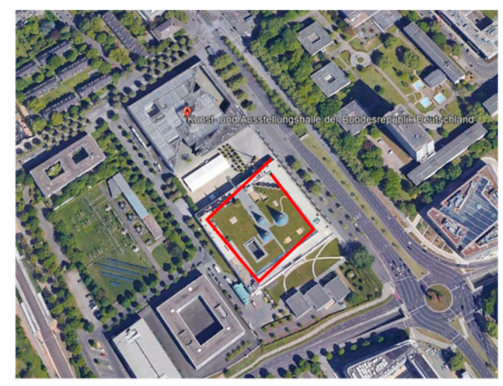

Art and Exhibition Hall - Germany

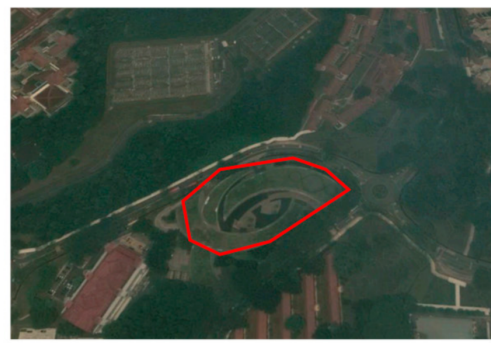

School of art, design and media - Singapore

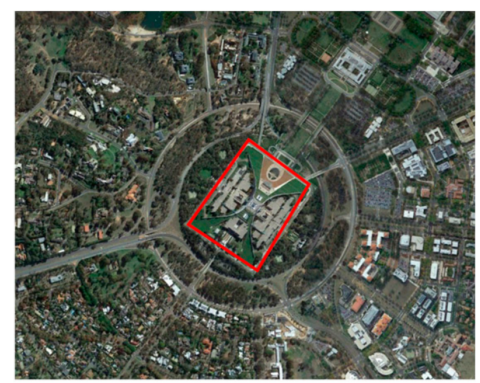

Seat of the Australian Parliament

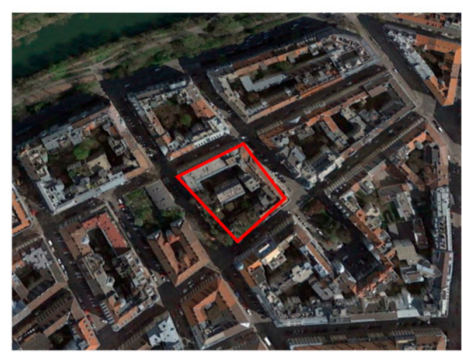

Hundertwasser - Vienna

Figure 5. Images showing the situation of some famous green roof (base maps from Google Maps).

Many countries, such as Germany, Canada and the United States, have forecast incentives to push the use of green technologies [113] such as green roofs. However, these incentives cannot represent the solution, because in their absence, companies will lose interest in adopting green technologies. Furthermore, the incentives can alter the market because the companies can adopt the solutions indicated by the incentives, and not just the best solution for the problem at hand. Thus, the incentives could produce an inefficient result or solutions that are not desirable [210]. Furthermore, they do not solve the problem of the absence of green areas in already existing industrial areas, which currently occupy the main urban area, and therefore, influence the generation of impacts on human health. Indeed, in the red area of Figure 6, it is possible to note the low presence of green spaces and the absence of green roofs on the whole. The use of green technologies in the industrial sector should instead be driven by a sustainable approach for industrial processes. The land use changes associated with industrialised areas must produce a mutual advantage for ecological, social and economic aspects [211,212]. Therefore, it is important to develop strategies and green solutions that can represent an investment for the companies to improve management business processes incorporating ecosystem services for reducing the cost and producing benefits for local populations. In this regard, it would be useful to develop economic tools that make it possible to quantify the added value produced by ecosystem services for companies. There have been different attempts to develop toolkits to estimate the monetary value of GI [8], but they are still under development.

It is clear that planning GI must be implemented through a transdisciplinary approach, which involves different experts from different disciplines, such as biologists who operate at different ecological scales ranging from single plants to the entire ecosystem, and planners who can operate at different urban scales, ranging from micro-, to meso- and macroscales $[40,87,213]$. It is crucial to generate interactions and the exchange of ideas between different disciplines through a multi-scale approach to maximise the benefits. Moreover, the planning must involve both institutional decision-makers and individual stakeholders who work on the regeneration of cities to develop an awareness of the social, ecological and economic benefits provided by GI. Planners have to consider green spaces as a social ecological system where there is a strong interaction between environmental conditions, 
economic purposes and social needs to identify ecosystem services issues. The ecological planning of GI in an urban space is not trivial but needs to consider specific questions following a specific framework, which can be seen in Figure 7.

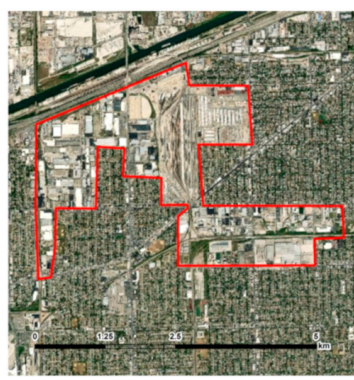

Chicago (US)

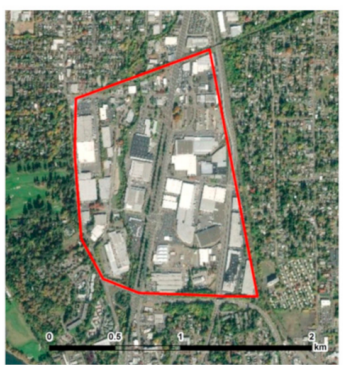

Portland (US)

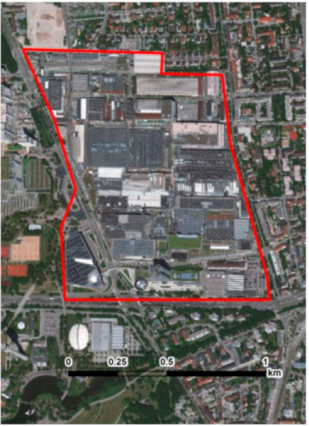

Munich (DE)

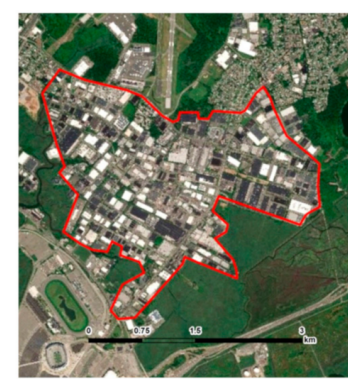

New York (US)

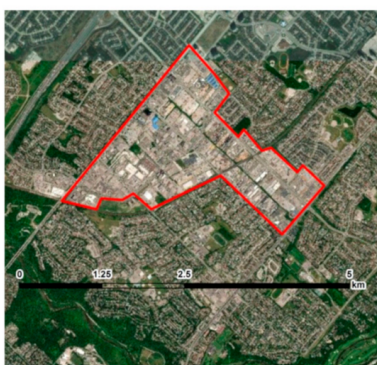

Toronto (CA)

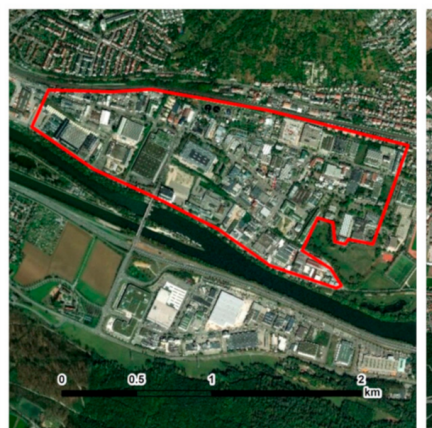

Esslingen (DE)

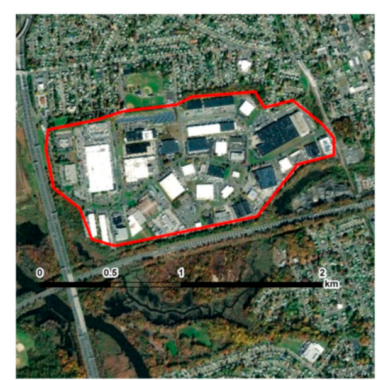

Philadelphia (US)

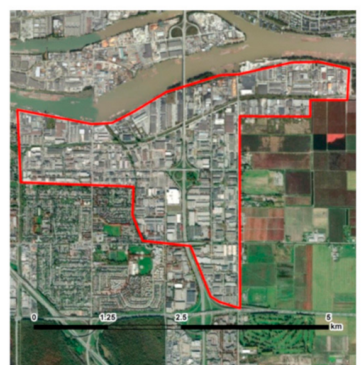

Vancouver (CA)

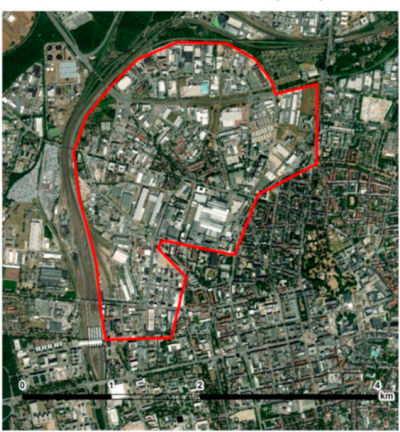

Darmstadt (DE)

Figure 6. Images showing the situation of the green spaces in industrial areas in cities where economic incentives for the installation of green roofs have been developed (base maps from Bing Maps).

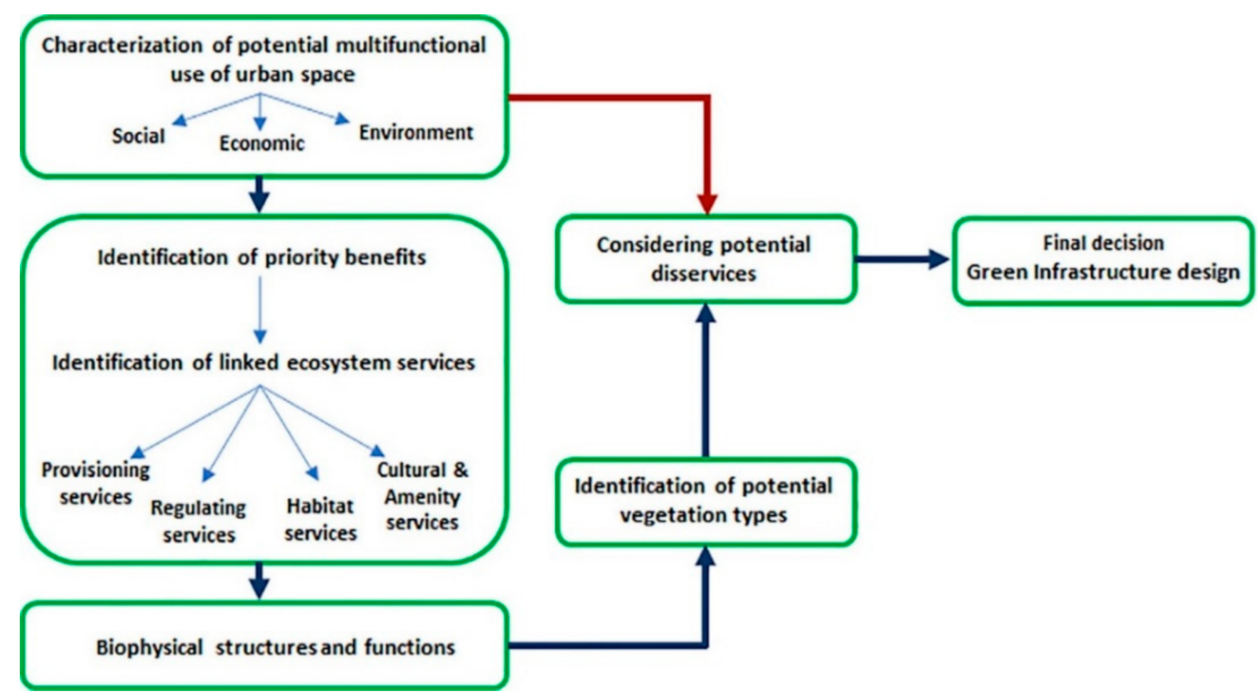

Figure 7. Schematic flow chart tailored to the ecological planning of green infrastructure. 


\section{Conclusions}

The present paper, starting from a general analysis of ecosystem services and benefits provided by GI, focuses on green roofs and urban community gardens as important strategies that are able to reduce the ecological footprint of urban areas in terms of energy resources consumption, waste recycling and food production. Of course, the dimension and shape of the engineered habitat can influence the capacity to support biodiversity and ecosystem services [45], but in the context of green roof and community gardens in urban areas, these can be secondary aspects as they are good alternatives to hyper-waterproofed surfaces or those with low ecological and social value. Moreover, the integration and promotion of GI in private spaces are important for amplifying the benefits that these solutions can bring to urban systems because many small solutions added together, and added to those made in public spaces, can have a holistic effect on mitigating urban impacts.

Such strategies are discussed from a new point of view that takes into consideration not only the simple introduction of vegetation for mitigation strategies but looks at the vegetation as an active part of the design of the urban space to maximise benefits and minimise negative effects. We are aware that the review is not exhaustive and a further analysis of the co-creation processes involving scientific and non-scientific stakeholders in relation to the challenge(s) at stake is foreseen; this aspect is indirectly considered by including some papers that used the stakeholder's involvement to analyse the ecosystem services and benefits provided by GI. Furthermore, an important aspect to consider is time, because human needs, scientific research, technology and environmental and urban policies evolve; therefore, ecological functions producing ecosystem services and disservices can evolve with them.

It is expected that this review opens to a new vision calling for a transdisciplinary approach focused to different scales, from single physiological processes of the vegetation to the neighbourhood and city scale involving scientists, decision-makers and business companies to choose the right GI system in the right place.

Author Contributions: Conceptualisation, T.S. and R.B.; methodology, T.S.; formal analysis, T.S., A.S. (Aurelia Scarano) and R.B.; resources, T.S.; writing-original draft preparation, T.S., A.S. (Aurelia Scarano), A.S. (Angelo Santino) and E.A.; writing-review and editing, T.S. and R.B.; visualisation, A.S. (Aurelia Scarano); supervision, R.B. All authors have read and agreed to the published version of the manuscript.

Funding: This research received no external funding.

Institutional Review Board Statement: Not applicable.

Informed Consent Statement: Not applicable.

Data Availability Statement: Data sharing not applicable.

Acknowledgments: We are grateful to Matteo Di Venosa from the University of Pescara (Italy) for helpful discussion and suggestions. A.S. (Aurelia Scarano) and A.S. (Angelo Santino) acknowledge the CNR-DiSBA project NutrAge (project nr. 7022).

Conflicts of Interest: The authors declare no conflict of interest.

\section{References}

1. Seto, K.; Shepherd, M.J. Global urban land-use trends and climate impacts. Curr. Opin. Environ. Sustain. 2009, 1, 89-95. [CrossRef]

2. Semeraro, T.; Aretano, R.; Pomes, A.; Del Giudice, C.; Nigro, D. Planning ground based utility scale solar energy as Green Infrastructure to enhance ecosystem services. Energy Policy 2018, 117, 218-227. [CrossRef]

3. The World Bank. Urban Population. Available online: https:// data.worldbank.org/indicator/SP.URB.TOTL.IN.ZS (accessed on 19 July 2020).

4. United Nations. The World's Cities in 2018. Available online: https://www.un.org/en/events/citiesday/assets/pdf/the_ worlds_cities_in_2018_data_booklet.pdf (accessed on 19 July 2020).

5. Suzuki, H.; Dastur, A.; Moffatt, S.; Yabuki, N.; Maruyama, H. Eco2 Cities. In Ecological Cities as Economic Cities; World Bank Publications: Washington, DC, USA, 2009.

6. Benedict, M.A.; McMahon, E.T. Green infrastructure: Smart conservation for the 21st century. Renew. Resour. J. 2002, 20, 12-17. 
7. Lafortezza, R.; Davies, C.; Sanesi, G.; Konijnendijk, C. Green Infrastructure as a tool to support spatial planning in European urban regions. iForest 2013, 6, 102-108. [CrossRef]

8. Oijstaeijen, W.V.; Van Passel, S.; Cools, J. Urban green infrastructure: A review on valuation toolkits from an urban planning perspective. J. Environ. Manag. 2019, 267, 110603. [CrossRef] [PubMed]

9. Semeraro, T.; Aretano, R.; Barca, A.; Pomes, A.; Del Giudice, C.; Gatto, E.; Lenucci, M.; Buccolieri, R.; Emmanuel, R.; Gao, Z.; et al. A Conceptual Framework to Design Green Infrastructure: Ecosystem Services as an Opportunity for Creating Shared Value in Ground Photovoltaic Systems. Land 2020, 9, 238. [CrossRef]

10. Vartholomaios, A.; Kalogirou, N.; Athanassiou, E.; Papadopoulou, M. The green space factor as a tool for regulating the urban microclimate in vegetation-deprived Greek cities. In Proceedings of the International Conference on "Changing Cities": Spatial, Morphological, Formal \& Socio-Economic Dimensions, Skiathos Island, Greece, 18-21 June 2013. [CrossRef]

11. Anguluri, R.; Narayanan, P. Role of green space in urban planning: Outlook towards smart cities. Urban For. Urban Green. 2017, 25, 58-65. [CrossRef]

12. World Health Organisation (WHO). Regional Office for Europe. Urban Green Spaces: A Brief for Action. Available online: https://www.euro.who.int/_data/assets/pdf_file/0010/342289/Urban-Green-Spaces_EN_WHO_web3.pdf\%3Fua=1 (accessed on 29 July 2020).

13. Grimmond, C.S.B.; King, T.S.; Cropley, F.D.; Nowak, D.; Souch, C. Local scale fluxes of carbon dioxide in urban environments: Methodological challenges and results from Chicago. Environ. Pollut. 2002, 116, S243-S254. [CrossRef]

14. Grimm, N.B.; Faeth, S.H.; Golubiewski, N.E.; Redman, C.L.; Wu, J.G.; Bai, X.M.; Briggs, J.M. Global change and the ecology of cities. Science 2008, 319, 756-760. [CrossRef]

15. Schlesinger, W.H. On the fate of anthropogenic nitrogen. Proc. Natl. Acad. Sci. USA 2009, 106, 203-208. [CrossRef]

16. Trenberth, K.E.; Jones, P.D.; Ambenje, P.; Bojariu, R.; Easterling, D.; Tank, A.K.; Parker, D.; Rahimzadeh, F.; Renwick, J.A.; Rusticucci, M.; et al. Observations: Surface and atmospheric climate change. In Climate Change 2007: The Physical Science Basis; Solomon, S., Qin, D., Manning, M., Chen, Z., Marquis, M., Averyt, K.B., Tignor, M., Miller., H.L., Eds.; In Contribution of Working Group I to the Fourth Assessment Report of the Intergovernmental Panel on Climate Change; Cambridge University Press: Cambridge, UK, 2007; pp. 237-336.

17. Harlan, S.L.; Ruddel, D. Climate change and health in cities: Impacts of heat and air pollution and potential co-benefits from mitigation and adaptation. Curr. Opin. Environ. Sustain. 2011, 3, 126-134. [CrossRef]

18. Pascal, M.; Corso, M.; Chanel, O.; Declercq, C.; Badaloni, G.; Henschel, S.; Meister, K.; Haluza, D.; Olmedo, P.M.; Medina, S. Assessing the public health impacts of urban air pollution in 25 European cities: Results of the Aphekom project. Sci. Total Environ. 2013, 449, 390-400. [CrossRef] [PubMed]

19. Hidalgo, J.; Masson, V.; Baklanov, A.; Pigeon, G.; Gimenoa, L. Advances in urban climate modeling: Trends and directions in climate research. Ann. N. Y. Acad. Sci. 2008, 1146, 354-374. [CrossRef] [PubMed]

20. Oke, T.R. Boundary Layer Climates; Methuen; Psychology Press: New York, NY, USA, 1987.

21. Ward, K.; Lauf, S.; Kleinschmit, B.; Endlicher, W. Heat waves and urban heat islands in Europe: A review of relevant drivers. Sci. Total Environ. 2016, 527-539. [CrossRef]

22. Rizwan, A.M.; Dennis, L.Y.C.; Liu, C. A review on the generation, determination and mitigation of Urban Heat Island. J. Environ. Sci. 2008, 20, 120-128. [CrossRef]

23. Qiu, G.; Li, H.; Zhang, Q.; Chen, W.; Liang, X.; Li, X. Effects of Evapotranspiration on Mitigation of Urban Temperature by Vegetation and Urban Agriculture. J. Integr. Agric. 2013, 12, 1307-1315. [CrossRef]

24. Hirano, Y.; Yoshida, Y. Assessing the effects of $\mathrm{CO}_{2}$ reduction strategies on heat islands in urban areas. Sustain. Cities Soc. 2016, 26, 383-392. [CrossRef]

25. Gartland, L. Heat Islands: Understanding and Mitigating Heat in Urban Areas; Routledge Press: London, UK, 2010.

26. Hsieh, C.M.; Huang, H.C. Mitigating urban heat islands: A method to identify potential wind corridor for cooling and ventilation. Comp. Environ. Urban Syst. 2016, 57, 130-143. [CrossRef]

27. Knowlton, K.; Rotkin-Ellman, M.; King, G.; Margolis, G.; Smith, D.; Solomon, G.; Trent, R.; English, P. The 2006 heat wave: Impacts on hospitalizations and emergency department visits. Environ. Health Perspect. 2009, 117, 61-67. [CrossRef]

28. Buchin, O.; Hoelscher, M.T.; Meier, F.; Nehls, T.; Ziegler, F. Evaluation of the health-risk reduction potential of countermeasures to urban heat islands. Energy Build. 2016, 114, 27-37. [CrossRef]

29. Walter, L.F.; Icaza, L.E.; Neht, A.; Klavins, M.; Morgan, E.A. Coping with the impacts of urban heat islands. A literature-based study on understanding urban heat vulnerability and the need for resilience in cities in a global climate change context. J. Clean. Prod. 2018, 171, 1140-1149. [CrossRef]

30. Stathopoulou, E.; Mihalakakou, G.; Santamouris, M.; Bagiorgas, H.S. On the impact of temperature on tropospheric ozone concentration levels in urban environments. J. Earth Syst. Sci. 2008, 117, 227-236. [CrossRef]

31. Santamouris, M. Regulating the damaged thermostat of the cities-Status, impacts and mitigation challenges. Energy Build. 2015, 91, 43-56. [CrossRef]

32. Field, C.B.; Barros, V.; Stocker, T.F.; Qin, D.; Dokken, D.J.; Ebi, K.L.; Mastrandrea, M.D.; Mach, K.J.; Plattner, G.-K.; Allen, S.K.; et al. Managing the Risks of Extreme Events and Disasters to Advance Climate Change Adaption. A Special Report of Working Groups I and II of the Intergovernmental Panel on Climate Change; Cambridge University Press: New York, NY, USA, 2012. 
33. Weng, Q. Remote sensing of impervious surfaces in the urban areas: Requirements, methods, and trends. Remote Sens. Environ. 2012, 117, 34-49. [CrossRef]

34. United Nations. Prototype Global Sustainable Development Report; United Nations Department of Economic and Social Affairs, Division for Sustainable Development: New York, NY, USA, 2014. Available online: http:/ / sustainabledevelopment.un.org/ globalsdreport/ (accessed on 19 July 2020).

35. United Nations. World Urbanization Prospects: The 2014 Revision, Highlights; Population Division, United Nations, Department of Economic and Social Affairs: 2014. New York. Available online: https:/ / population.un.org/wup/Publications/Files/WUP2014Report.pdf (accessed on 26 July 2020).

36. Kaspersen, P.S.; Ravn, N.H.; Nielsen, K.A.; Madsen, H.; Drewa, M. Comparison of the impacts of urban development and climate change on exposing European cities to pluvial flooding. Hydrol. Earth Syst. Sci. 2017, 21, 4131-4147. [CrossRef]

37. Millennium Ecosystem Assessment (MEA). Ecosystems and Human Well-Being: Current State and Trends; Island Press: Washington, DC, USA, 2005.

38. Garcia-Nieto, A.P.; Geijzendorffer, I.R.; Barò, F.; Roche, P.K.; Bondeau, A.; Cramer, W. Impacts of urbanization around Mediterranean cities: Changes in ecosystem service supply. Ecol. Indic. 2018, 91, 589-606. [CrossRef]

39. Bowler, D.E.; Buyung-Ali, L.; Knight, T.M.; Pullin, A.S. Urban greening to cool towns and cities: A systematic review of the empirical evidence. Landsc. Urban Plan. 2010, 97, 147-155. [CrossRef]

40. Maggiore, G.; Semeraro, T.; Aretano, R.; De Bellis, L.; Luvisi, A. GIS Analysis of Land-Use Change in Threatened Landscapes by Xylella fastidiosa. Sustainability 2019, 11, 253. [CrossRef]

41. Smith, R.M.; Thompson, K.; Hodgson, J.G.; Warren, P.H.; Gaston, K.J. Urban domestic gardens (IX): Composition and richness of the vascular plant flora, and implications for native biodiversity. Biol. Conserv. 2006, 129, 312-322. [CrossRef]

42. Kendal, D.; Williams, N.S.; Williams, K.J. Drivers of diversity and tree cover in gardens, parks and streetscapes in an Australian city. Urban For. Urban Green. 2012, 11, 257-265. [CrossRef]

43. Hadavi, S.; Kaplan, R.; Hunter, M.C.R. Environmental affordances: A practical approach for design of nearby outdoor settings in urban residential areas. Landsc. Urban Plan. 2015, 134, 19-32. [CrossRef]

44. Farahani, L.M.; Maller, C. Perceptions and Preferences of Urban Greenspaces: A Literature Review and Framework for Policy and Practice. Landsc. Online 2018, 61, 1-22. [CrossRef]

45. Salbitano, F.; Borelli, S.; Conigliaro, M.; Chen, Y. Guidelines on Urban and Peri-Urban Forestry; FAO Forestry Paper No.178; Food and Agriculture Organization of the United Nations: Rome, Italy, 2016.

46. De Groot, R.; Fisher, B.; Christie, M.; Aronson, J.; Braat, L.; Gowdy, J.; Haines-Young, R.; Maltby, E.; Neuville, A.; Polasky, S.; et al. Integrating the ecological and economic dimensions in biodiversity and ecosystem service valuation. In The Economics of Ecosystems and Biodiversity Ecological and Economic Foundations; Kumar, P., Ed.; Routledge Press: London, UK, 2010 ; pp. 9-40.

47. De Groot, R.; Brander, L.; van der Ploeg, S.; Costanza, R.; Bernard, F.; Braat, L.; Christie, M.; Crossman, N.; Ghermandi, A.; Hein, L.; et al. Global estimates of the value of ecosystems and their services in monetary units. Ecosyst. Serv. 2012, 1, 50-61. [CrossRef]

48. Schwartz, M.W.; Hiers, J.K.; Davis, F.W.; Garfin, G.M.; Jackson, S.T.; Terando, C.J.; Woodhouse, C.A.; Morelli, T.L.; Williamson, M.A.; Brunson, M.W. Developing a translational ecology workforce. Front. Ecol. Environ. 2017, 15, 587-596. [CrossRef]

49. Moher, D.; Liberati, A.; Tetzlaff, J.; Altman, D.G. The PRISMA Group. Preferred Reporting Items for Systematic Reviews and Meta-Analyses: The PRISMA Statement. PLoS Med 2009, 6, e1000097. [CrossRef]

50. Roy, S.; Byrne, J.; Pickering, C. A systematic quantitative review of urban tree benefits, costs, and assessment methods across cities in different climatic zones. Urban For. Urban Green. 2012, 11, 351-363. [CrossRef]

51. Livesley, S.J.; McPherson, E.G.; Calfapietra, C. The urban forest and ecosystem services: Impacts on urban water, heat, and pollution cycles at the tree, street, and city scale. J. Environ. Qual. 2016, 45, 119-124. [CrossRef]

52. Salmond, J.A.; Tadaki, M.; Vardoulakis, S.; Arbuthnott, K.; Coutts, A.; Demuzere, M.; Dirks, K.N.; Heaviside, C.; Lim, S.; Macintyre, H.; et al. Health and climate related ecosystem services provided by street trees in the urban environment. Environ. Health 2016, 15, 36. [CrossRef]

53. Santamouris, M.; Ban-Weiss, G.; Osmond, P.; Paolini, R.; Synnefa, A.; Cartalis, C.; Muscio, A.; Zinzi, M.; Morakinyo, T.E.; $\mathrm{Ng}$, E.; et al. Progress in urban greenery mitigation science-assessment methodologies advanced technologies and impact on cities. J. Civ. Eng. Manag. 2018, 24, 638-671. [CrossRef]

54. Tratalos, J.; Fuller, R.A.; Warren, P.H.; Davies, R.G.; Gaston, K.J. Urban form, biodiversity potential and ecosystem services. Landsc. Urban Plan. 2007, 83, 308-317. [CrossRef]

55. La Rosa, D.; Spyra, M.; Inostranza, L. Indicators of Cultural Ecosystem Services for urban planning: A review. Ecol. Indic. 2016, 61, 74-89. [CrossRef]

56. Semeraro, T.; Aretano, R.; Pomes, A. Green Roof Technology as a Sustainable Strategy to Improve Water Urban Availability. IOP Conf. Ser. Mater. Sci. Eng. 2019, 471, 092065. [CrossRef]

57. Thompson, C.W.; Roe, J.; Aspinall, P.; Mitchell, R.; Clow, A.; Miller, D. More green space is linked to less stress in deprived communities: Evidence from salivary cortisol patterns. Landsc. Urban Plan. 2012, 105, 221-229. [CrossRef]

58. Sandifer, P.; Sutton-Grier, A.E.; Ward, B.P. Exploring connections among nature, biodiversity, ecosystem services, and human health and well-being: Opportunities to enhance health and biodiversity conservation. Ecosyst. Serv. 2015, 12, 1-15. [CrossRef] 
59. Semeraro, T.; Gatto, E.; Buccolieri, R.; Vergine, M.; Gao, Z.; De Bellis, L.; Luvisi, A. Changes in Olive Urban Forests Infected by Xylella fastidiosa: Impact on Microclimate and Social Health in urban areas. Int. J. Environ. Res. Public Health 2019, 16, 2642. [CrossRef]

60. Nuissl, H.; Haase, D.; Lanendorf, M.; Wittemer, H. Environmental impact assessment of urban land use transitions-A contextsensitive approach. Land Use Policy 2009, 26, 414-424. [CrossRef]

61. The Economics of Ecosystems and Biodiversity (TEEB). TEEB Manual for Cities: Ecosystem Services in Urban Management. 2011. Available online: www.teebweb.org (accessed on 1 July 2020).

62. Sieber, J.; Pons, M. Assessment of Urban Ecosystem Services using Ecosystem Services Reviews and GIS-based Tools. Procedia Eng. 2015, 115, 53-60. [CrossRef]

63. De Groot, R.S. Function-analysis and valuation as a tool to assess land use conflicts in planning for sustainable, multi-functional landscapes. Landsc. Urban Plan. 2006, 75, 175-186. [CrossRef]

64. Bernstein, A.S. Biological diversity and human health. Annu. Rev. Public Health 2014, 35, 153-167. [CrossRef]

65. Miller, M.S.; Montalto, F.A. Stakeholder perceptions of the ecosystem services provided by Green Infrastructure in New York City. Ecosyst. Serv. 2019, 37, 100928. [CrossRef]

66. Lin, B.L.; Egerer, M.H. Global social and environmental change drives the management and delivery of ecosystem services from urban gardens: A case study from Central Coast, California. Glob. Environ. Chang. 2020, 60, 102006. [CrossRef]

67. Ramyar, R.; Saeedi, S.; Bryant, M.; Davatgar, A.; Hedjri, G.M. Ecosystem services mapping for green infrastructure planning-The case of Tehran. Sci. Total Environ. 2020, 703, 135466. [CrossRef] [PubMed]

68. Hyun, K.J. Impacts of urban greenspace on offsetting carbon emissions for middle Korea. J. Environ. Manag. 2002, 64, 115-126. [CrossRef]

69. Pope, C.A., 3rd; Essati, M.; Dockery, D.W. Fine-particulate air pollution and life expectancy in the United States. N. Engl. J. Med. 2009, 360, 376-386. [CrossRef]

70. Hunt, A.; Watkiss, P. Climate change impacts and adaptation in cities: A review of the literature. Clim. Chang. 2011, 104, 13-49. [CrossRef]

71. Setälä, H.; Viippola, V.; Rantalainen, A.L.; Pennanen, A.; Yli-Pelkonen, V. Does urban vegetation mitigate air pollution in northern conditions? Environ. Pollut. 2013, 183, 104-112. [CrossRef]

72. Majekodunmi, M.; Emmanuel, R.; Jafry, T. A spatial exploration of deprivation and green infrastructure ecosystem services within Glasgow city. Urban For. Urban Green. 2020, 52, 126698. [CrossRef]

73. Tian, Y.; Wu, H.; Zhang, G.; Wang, L.; Zheng, D.; Li, S. Perceptions of ecosystem services, disservices and willingness-to-pay for urban green space conservation. J. Environ. Manag. 2020, 260, 110140. [CrossRef]

74. Song, P.; Kim, G.; Mayer, A.; He, R.; Tian, G. Assessing the Ecosystem Services of Various Types of Urban Green Spaces Based on i-Tree Eco. Sustainability 2020, 12, 1630. [CrossRef]

75. Chen, S.; Wang, Y.; Ni, Z.; Zhang, X.; Xia, B. Benefits of the ecosystem services provided by urban green infrastructures: Differences between perception and measurements. Urban For. Urban Green. 2020, 54, 126774. [CrossRef]

76. Havenith, G.; Luttikholt, V.G.M.; Vrijkotte, T.G.M. The relative influence of body characteristics on humid heat stress response. Eur. J. Appl. Physiol. 1995, 70, 270-279. [CrossRef] [PubMed]

77. Curriero, F.C.; Heiner, K.S.; Samet, J.M.; Zeger, S.L.; Strug, L.; Patz, J.A. Temperature and mortality in 11 cities of the eastern United States. Am. J. Epidemiol. 2002, 155, 80-97. [CrossRef]

78. Bentley, M. Healthy Cities, local environmental action and climate change. Health Promot. Int. 2007, 22, 246-253. [CrossRef] [PubMed]

79. Thorsson, S.; Honjo, T.; Lindberg, F.; Eliasson, I.; Lim, E.M. Thermal comfort and outdoor activity in Japanese urban public places. Environ. Behav. 2007, 39, 660-684. [CrossRef]

80. McMichael, A.J.; Wilkinson, P.; Kovats, S.; Pattenden, S.; Hajat, S.; Armstrong, B.; Vajanapoom, N.; Niciu, E.M.; Mahomed, H.; Kingkeow, C.; et al. International study of temperature, heat and urban mortality: The 'ISOTHURM' project. Int. J. Epidem. 2008, 37, 1121-1131. [CrossRef]

81. O'Neill, M.S.; Ebi, K.L. Temperature extremes and health: Impacts of climate variability and change in the United States. J. Occup. Environ. Med. 2009, 51, 13-25. [CrossRef]

82. Gatto, E.; Buccolieri, R.; Aarrevaara, E.; Ippolito, F.; Emmanuel, R.; Perronace, L.; Santiago, J.L. Impact of Urban Vegetation on Outdoor Thermal Comfort: Comparison between a Mediterranean City (Lecce, Italy) and a Northern European City (Lahti, Finland). Forests 2020, 11, 228. [CrossRef]

83. Butler, D.; Davies, J.W. Urban Drainage; Spon Press: London, NY, USA, 2011.

84. Hall, J.; Arheimer, B.; Borga, M.; Brázdil, R.; Claps, P.; Kiss, A.; Kjeldsen, T.R.; Kriauciuniene, J.; Kundzewicz, Z.W.; Lang, M.; et al. Understanding flood regime changes in Europe: A state-of-the-art assessment. Hydrol. Earth Syst. Sci. 2014, 18, $2735-2772$. [CrossRef]

85. Lindemann-Matthies, P.; Junge, X.; Matthies, D. The influence of plant diversity on people's perception and aesthetic appreciation of grassland vegetation. Biol. Conserv. 2010, 143, 195-202. [CrossRef]

86. Park, B.-J.; Furuya, K.; Kasetani, T.; Takayama, N.; Kagawa, T.; Miyazaki, Y. Relationship between psychological responses and physical environments in forest settings. Landsc. Urban Plan. 2011, 102, 24-32. [CrossRef] 
87. Semeraro, T.; Zaccarelli, N.; Lara, A.; Sergi-Cucinelli, F.; Aretano, R. A Bottom-Up and Top-Down Participatory Approach to Planning and Designing Local Urban Development: Evidence from an Urban University Center. Land 2020, 9, 98. [CrossRef]

88. Jennings, V.; Bamkole, O. The Relationship between Social Cohesion and Urban Green Space: An Avenue for Health Promotion. Int. J. Environ. Res. Public Health 2019, 16, 452. [CrossRef] [PubMed]

89. Perone, P.; Cocozza, C.; Cherubini, P.; Bachmann, O.; Guillong, M.; Lasserre, B.; Marchetti, M.; Tognetti, R. Oak tree-rings record spatial-temporal pollution trends from different sources in Terni (Central Italy). Environ. Pollut. 2018, 233, 278-289. [CrossRef] [PubMed]

90. Alterio, E.; Rizzi, A.; Chirici, G.; Cocozza, C.; Sitzia, T. Preserving air pollution forest archives accessible through dendrochemistry. J. Environ. Manag. 2020, 264, 110462. [CrossRef] [PubMed]

91. Semeraro, T.; Luvisi, A.; De Bellis, L.; Aretano, R.; Sacchelli, S.; Chirici, G.; Marchetti, M.; Cocozza, C. Dendrochemistry: Ecosystem services perspectives for urban biomonitoring. Front. Environ. Sci. 2020, 8, 558893. [CrossRef]

92. Lambin, E.F.; Meyfroidt, P. Land use transitions: Socio-ecological feedback versus socio-economic change. Land Use Policy 2010, 27, 108-118. [CrossRef]

93. Kourdounouli, C.; Jönsson, A.M. Urban ecosystem conditions and eco system services-A comparison between large urban zones and city cores in the EU. J. Environ. Plan. Manag. 2019, 63, 798-817. [CrossRef]

94. Carter, T.; Butler, C. Ecological impacts of replacing traditional roofs with green roofs in two urban areas. Cities Environ. 2008, 1, 17. [CrossRef]

95. Department of Planning and Local Government. Rain Gardens, Green Roof Sand Infiltration Systems. In Water Sensitive Urban Design Technical Manual; Government of South Australia: Adelaide, Australia, 2010; pp. 12-21.

96. GSA. The Benefits and Challenges of Green Roofs on Public and Commercial Buildings. A Report of the United States General Service Administration, US GSA. 2011. Available online: https:/ / www.gsa.gov / cdnstatic/The_Benefits_and_Challenges_of_ Green_Roofs_on_Public_and_Commercial_Buildings.pdf (accessed on 10 July 2020).

97. Dunnett, N.; Kingsbury, N. Planting Green Roofs and Living Walls; Timber Press: Portland, OR, USA, 2004.

98. Dunnett, N.; Kingsbury, N. Planting options for extensive and semi-extensive green roofs. The Cardinal Group, Toronto. In Proceedings of the 2nd Annual Greening Rooftops for Sustainable Communities Conference, Portland, OR, USA, 2-4 June 2004.

99. Wong, J.K.W.; Lau, L.S.-K. From the 'urban heat island' to the 'green island'? A preliminary investigation into the potential of retrofitting green roofs in Mongkok district of Hong Kong. Habitat Int. 2013, 39, 25-35. [CrossRef]

100. Korola, E.; Shushunova, N. Benefits of A Modular Green Roof Technology. Procedia Eng. 2016, 161, 1820-1826. [CrossRef]

101. Shafique, M.; Kim, R.; Rafiq, M. Green roof benefits, opportunities and challenges-A review. Renew. Sustain. Energy Rev. 2018, 90, 757-773. [CrossRef]

102. Harzmann, U. German green roofs. In Proceedings of the Annual Green Roof Construction Conference; Chicago, IL, USA, 1 July 2003. Available online: https:/ / www.osti.gov / etdeweb/biblio/20398172 (accessed on 26 July 2020).

103. Moran, A. A North Carolina Field Study to Evaluate Greenroof Runoff Quantity, Runoff Quality, and Plant Growth. Master's Thesis, North Carolina State University, Raleigh, NC, USA, 2004.

104. Mentens, J.; Raes, D.; Hermy, M. Green roofs as a tool for solving the rainwater runoff problem in the urbanized 21st century? Landsc. Urban Plan. 2006, 77, 217-226. [CrossRef]

105. Toronto Food Policy Council (TFPC). Feeding the City from the Back Forty: A Commercial Food Production Plan for the City of Toronto; Toronto Public Library: Toronto, ON, Canada, 1999.

106. Sheung, L.L. Rooftop Garden: Planting Seeds of Service, Teacher's Network. Available online: http:/ / www.teachnet.org/docs/ Network/Project/Boston/Sheung/ (accessed on 26 July 2020).

107. Nowak, M. Urban Agriculture on the Rooftop. Senior honors Thesis, Cornell University, New York, NY, USA, 2004.

108. Huang, X. Investigation of roof agriculture development. Res. Environ. Sci. 2010, 9, 316-317.

109. Whittinghill, L.J.; Rowe, D.B. The role of green roof technology in urban agriculture. Renew. Agric. Food Syst. 2012, $27,314-322$. [CrossRef]

110. Phoomirat, R.; Disyatat, N.R.; Park, T.Y.; Lee, D.K.; Dumrongrojwatthana, P. Rapid assessment checklist for green roof ecosystem services in Bangkok. Ecol. Process. 2020, 9, 19. [CrossRef]

111. Langemeyer, J.; Wedgwood, D.; McPhearsonc, T.; Baró, F.; Madsende, A.L.; Barton, D.N. Creating urban green infrastructure where it is needed-A spatial ecosystem service-based decision analysis of green roofs in Barcelona. Sci. Total Environ. 2020, 707, 135487. [CrossRef]

112. Getter, K.L.; Rowe, D.B. The role of extensive green roofs in sustainable development. HortScience 2006, 41, 1276-1285. [CrossRef]

113. Berardi, U.; Hoseini, A.H.G.; Hoseini, A.G. State-of-the-art analysis of the environmental benefits of green roofs. Appl. Energy 2014, 115, 411-428. [CrossRef]

114. Chow, M.F.; Bakar, F.A. A Review on the Development and Challenges of Green Roof Systems in Malaysia. World Acad. Sci. Eng. Technol. Int. J. Archit. Environ. Eng. 2016, 10, 16-20.

115. Liu, K.; Baskaran, B. Thermal performance of green roofs through field evaluation. The Cardinal Group, Toronto. In Proceedings of the 1st North American Green Roof Conferences: Greening Rooftops for Sustainable Communities, Chicago, IL, USA, 29-30 May 2003; pp. 273-282.

116. Lazzarin, R.M.; Castellotti, F.; Busato, F. Experimental measurements and numerical modeling of a green roof. Energy Build. 2005, 37, 1260-1267. [CrossRef] 
117. Carter, T.; Keeler, A. Life-cycle cost-benefit analysis of extensive vegetated roof systems. J. Environ. Manag. 2008, 87, 350-363. [CrossRef] [PubMed]

118. Sproul, J.; Wan, M.P.; Mandel, B.H.; Rosenfeld, A.H. Economic comparison of white, green, and black flat roofs in the United States. Energy Build. 2014, 71, 20-27. [CrossRef]

119. Sanchez, L.; Reames, T.G. Cooling Detroit: A socio-spatial analysis of equity in green roofs as an urban heat island mitigation strategy. Urban For. Urban Green. 2019, 44, 126331. [CrossRef]

120. Van Woert, N.D.; Rowe, D.B.; Andresen, J.A.; Rugh, C.L.; Fernandez, R.T.; Xiao, L. Green roof Stormwater Retention: Effects of Roof Surface, Slope, and Media Depth. J. Environ. Qual. 2005, 34, 1036-1044. [CrossRef] [PubMed]

121. Carter, T.; Rasmussen, T. Hydrologic behavior of vegetated roofs. J. Am. Water Resour. Assoc. 2006, 42, 1261-1274. [CrossRef]

122. Stovin, V. The potential of green roofs to manage Urban Stormwater. Water Environ. J. 2010, 24, 192-199. [CrossRef]

123. Brenneisen, S. The benefits of biodiversity from green roofs: Key design consequences. The Cardinal Group, Toronto. In Proceedings of the 1st North American Green Roof Conference: Greening Rooftops for Sustainable Communities, Chicago, IL, USA, 29-30 May 2003; pp. 323-329.

124. Brenneisen, S. Biodiversity strategy on green roofs. The Cardinal Group, Toronto. In Proceedings of the 3rd North American Green Roof Conference: Greening Rooftops for Sustainable Communities, Washington, DC, USA, 4-6 May 2005 ; pp. 449-456.

125. Coffman, R.; Davis, G. Insect and avian fauna presence on the Ford assembly plant ecoroof. The Cardinal Group, Toronto. In Proceedings of the 3rd North American Green Roof Conference: Greening Rooftops for Sustainable Communities, Washington, DC, USA, 4-6 May 2005; pp. 457-468.

126. Rafida, S.; Rahman, A.; Ahmad, H. Green Roof As Urban Antidote: A Review on Aesthetic, Environmental, Economic and Social Benefits. In Proceedings of the 6th South East Asian Technical Consortium in King Mongkut University of Technology Thonbur, Bangkok, Thailand, 20-23 October 2012; p. 4.

127. Kaiser, A.S.; Zamora, B.; Mazón, R.; García, J.R.; Vera, F. Experimental study of cooling BIPV modules by forced convection in the air channel. Appl. Energy 2014, 135, 88-97. [CrossRef]

128. Hui, S.C.M.; Chan, S.C. Integration of green roof and solar photovoltaic systems. In Proceedings of the Joint Symposium 2011: Integrated Building Design in the New Era of Sustainability, Hong Kong, 22 November 2011; pp. 1.1-1.10.

129. Chemisana, D.; Lamnatou, C. Photovoltaic-green roofs: An experimental evaluation of system performance. Appl. Energy 2014, 119, 246-256. [CrossRef]

130. Lamnatou, C.; Chemisana, D. A critical analysis of factors affecting photovoltaic green roof performance. Renew. Sustain. Energy Rev. 2015, 43, 264-280. [CrossRef]

131. Shafique, M.; Kim, R.; Lee, D. The potential of green-blue roof to manage storm water in urban areas. Nat. Environ. Poll. Technol. 2016, 15, 715-719.

132. Shafique, M.; Lee, D.; Kim, R. A field study to evaluate runoff quantity from blue roof and green blue roof in an urban area. Int. J. Control. Autom. 2016, 9, 59-68. [CrossRef]

133. Luo, T.; Young, R.; Reig, P. Aqueduct Projected Water Stress Rankings; Technical Note; World Resources Institute: Washington, DC, USA, 2015; Available online: http:/ / www.wri.org/publication/aqueduct-projected-water-stress-country-rankings (accessed on 26 July 2020).

134. Food and Agriculture Organization of the United Nations. Profitability and Sustainability of Urban and Peri-urban Agriculture; FAO: Rome, Italy, 2007.

135. Satterthwaite, D.; McGranahan, G.; Tacoli, C. Urbanization and its implications for food and farming. Philos. Trans. R. Soc. Lond. B. Biol. Sci. 2010, 365, 2809-2820. [CrossRef] [PubMed]

136. Martellozzo, F.; Landry, J.S.; Plouffe, D.; Seufert, V.; Rowhani, P.; Ramankutty, N. Urban agriculture: A global analysis of the space constraint to meet urban vegetable demand. Environ. Res. Lett. 2014, 9, 1-8. [CrossRef]

137. Egerer, M.; Fairbairn, M. Gated gardens: Effects of urbanization on community formation and commons management in community gardens. Geoforum 2018, 96, 61-69. [CrossRef]

138. Koopmans, M.; Keech, D.; Sovova, L.; Reed, M. Urban agriculture and place-making: Narratives about place and space in Ghent, Brno and Bristol New frontiers for urban community garden. Morav. Geogr. Rep. 2017, 25, 154-165. [CrossRef]

139. Viljoen, A.; Bohn, K.; Howe, J. Continuous Productive Urban Landscapes: Designing Urban Agriculture for Sustainable Cities; Architectural Press: Oxford, UK, 2005.

140. Duží, B.; Tóth, A.; Bihuňová, M.; Stojanov, R. Challenges of Urban Agriculture: Highlights on the Czech and Slovak Republic Specifics. In Current Challenges of Central Europe: Society and Environment; Vávra, J., Lapka, M., Cudlínová, E., Eds.; Univerzita Karlova v Praze, Filozofická Fakulta: Praha, Czech, 2014; pp. 82-107. ISBN 978-80-7308-551-3.

141. Taylor, J.R.; Lovell, S.T. Urban home food gardens in the Global North: Research traditions and future directions. Agric. Hum. Values 2013, 31, 285-305. [CrossRef]

142. Bousse, Y.S. Mitigating the Urban Heat Island Effect with an Intensive Green Roof during Summer in Reading, UK. Master's Thesis, Reading University, Reading, UK, 2009.

143. Sanye-Mengual, E.; Oliver-Sola, J.; Anton, A.; Montero, J.I.; Rieradevail, J. Environmental assessment of urban horticulture structures: Implementing rooftop greenhouses in Mediterranean cities. In Proceedings of the LCA Food Conference, San Francisco, CA, USA, 8-10 October 2014. 
144. Martin, G.; Clift, R.; Chistie, I. Urban Cultivation and Its Contributions to Sustainability: Nibbles of Food but Oodles of Social Capital. Sustainability 2016, 8, 409. [CrossRef]

145. De Zeeuw, H. Cities, climate change and urban agriculture. Urban Agric. Mag. 2011, 25, 39-42.

146. Lawson, L.J. City Bountiful: A Century of Community Gardening in America; University of California Press: Berkeley, CA, USA, 2005.

147. Levkoe, C.Z. Learning democracy through food justice movements. Agric. Human Values 2006, 23, 89-98. [CrossRef]

148. Ellis, R. Sowing the seeds of democracy: Community gardening in Parkdale, Toronto. Master's Thesis, University of Western Ontario, Toronto, ON, Canada, 2010.

149. Miedema, J.M.; Desjardins, E.; Marshall, K. ‘Not Just a Passing Fancy': How community gardens contribute to healthy and inclusive neighbourhoods. In Waterloo Region Public Health; AgriUrban: Quèbec, QC, Canada, 2013; Available online: http://chd. region.waterloo.on.ca/en/researchResourcesPublications/resources/Community_Gardening_Storytelling_Project.pdf (accessed on 20 June 2020).

150. McClintock, N. Why farm the city? Theorizing urban agriculture through a lens of metabolic rift. Camb. J. Reg. Econ. Soc. 2010, 3, 191-207. [CrossRef]

151. Mares, T.M.; Pena, D.G. Environmental and food justice. In Cultivating Food Justice: Race, Class, and Sustainability; Alkon, A.H., Agyeman, J., Eds.; MIT Press: Boston, MA, USA, 2011; pp. 197-219.

152. White, M.M. D-town farm: African American resistance to food insecurity and the transformation of Detroit. Environ. Pract. 2011, 13, 406-417. [CrossRef]

153. Gray, L.; Guzman, P.; Glowa, K.M.; Drevno, A.G. Can home gardens scale up into movements for social change? The role of home gardens in providing food security and community change in San Jose, California. Local Environ. Int. J. Justice Sustain. 2013. [CrossRef]

154. Binns, T.; Lynch, K. Feeding Africa's Growing Cities into the 21st Century: The potential of urban agriculture. J. Int. Dev. 1998, 10, 777-793. [CrossRef]

155. Buchmann, C. Cuban Home Gardens and Their Role in Social-Ecological Resilience. Hum. Ecol. 2009, 37, 705. [CrossRef]

156. Draper, C.; Freedman, D. Review and Analysis of the Benefits, Purposes, and Motivations Associated with Community Gardening in the United States. J. Community Pract. 2010, 18, 458-492. [CrossRef]

157. Kortright, R.; Wakefield, S. Edible backyards: A qualitative study of household food growing and its contributions to food security. Agric. Hum. Values 2011, 28, 39-53. [CrossRef]

158. Hodgson, K.; Campbell, M.C.; Bailkey, M. Urban Agriculture: Growing Healthy Sustainable Places. Am. Plan. Assoc. Plan. Advis. Serv. Rep. 2011, 563, 1-34.

159. Reynolds, K. Expanding technical assistance for urban agriculture: Best practices for extension services in California and beyond. J. Agric. Food Syst. Community Dev. 2011, 1, 1-20. [CrossRef]

160. Guitart, D.; Pickering, C.; Byrne, J. Past results and future directions in urban community gardens research. Urban For. Urban Green. 2012, 11, 364-373. [CrossRef]

161. Guitart, D.A.; Pickering, C.M.; Byrne, J.A. Color me healthy: Food diversity in school community gardens in two rapidly urbanising Australian cities. Health Place 2014, 26, 110-117. [CrossRef]

162. Poulsen, M.; Hulland, K.R.S.; Gulas, C.A.; Pham, H.; Dalglish, S.L.; Wilkinson, R.K.; Winch, P.J. Growing an Urban Oasis: A Qualitative Study of the Perceived Benefits of Community Gardening in Baltimore, Maryland. Cult. Agric. Food Environ. 2014, 36, 69-82. [CrossRef]

163. Napawan, N.C. Complexity in urban agriculture: The role of landscape typologies in promoting urban agriculture's growth. J. Urban. Int. Res. Placemaking Urban Sustain. 2014, 9, 1-20. [CrossRef]

164. Specht, K.; Siebert, R.; Hartmann, I.; Freisinger, U.B.; Sawicka, M.; Werner, A.; Thomaier, S.; Henckel, D.; Walk, H.; Dierich, A. Urban agriculture of the future: An overview of sustainability aspects of food production in and on buildings. Agric. Hum. Values 2014, 31, 33-51. [CrossRef]

165. Lal, R. Home gardening and urban agriculture for advancing food and nutritional security in response to the COVID-19 pandemic. Food Sec. 2020, 12, 871-876. [CrossRef] [PubMed]

166. Royal Commission on Environmental Pollution. Twenty Sixth Report: The Urban Environment; The Stationery Office (TSO): London, UK, 2007.

167. Rees, A.; Melix, B. Landscape Discourse and Community Garden Design in a Midsized Southern City. Stud. Hist. Gard. Des. Landsc. 2019, 39, 90-104. [CrossRef]

168. Ellingsen, E.; Despommier, D. The Vertical Farm-The origin of a 21st century Architectural Typology. CTBUH J. 2008, 3, 26-34.

169. Gorgolewski, M.; Komisar, J.; Nasr, J. Carrot City: Creating places for Urban Agriculture; The Monacelli Press: New York, NY, USA, 2011.

170. Komisar, J.; Nasr, J.; Gorgolewski, M. Designing for food and agriculture: Recent explorations at Ryerson University. Open House Int. 2009, 34, 61-70. [CrossRef]

171. Bohn, K.; Viljoen, A. The edible city: Envisioning the Continuous Productive Urban Landscape (CPUL). Field J. $2011,4,149-161$.

172. Lyytimäki, J.; Sipilä, M. Hopping on one leg-The challenge of ecosystem disservices for urban green management. Urban For. Urban Green. 2009, 8, 309-315. [CrossRef]

173. Von Döhren, P.; Haase, D. Ecosystem disservices research: A review of the state of the art with a focus on cities. Ecol. Indic. 2015, 52, 490-497. [CrossRef] 
174. Shackleton, C.M.; Ruwanza, S.; Sanni, K.S.; Bennet, S.; De Lacy, P.; Modipa, R.; Mtati, N.; Sachikonye, M.; Thondhlana, G. Unpacking Pandora's Box: Understanding and Categorising Ecosystem Disservices for Environmental Management and Human Wellbeing. Ecosystems 2015, 19, 587-600. [CrossRef]

175. Schaubroeck, T. A need for equal consideration of ecosystem disservices and services when valuing nature; countering arguments against disservices. Ecosyst. Serv. 2017, 26, 95-97. [CrossRef]

176. Lyytimäki, J. Disservices of urban trees. In Routledge Handbook of Urban Forestry; Ferrini, F., van den Bosch, C.C.K., Fini, A., Eds.; Routledge: London, UK, 2017; pp. 164-176. [CrossRef]

177. Witzling, L.; Wander, M.; Phillips, E. Testing and educating on urban soil lead: A case of Chicago community gardens. J. Agric. Food Sys. Community Dev. 2011, 1, 167-185. [CrossRef]

178. Lyytimäki, J. Bad nature: Newspaper representations of ecosystem disservices. Urban For. Urban Green. 2014, 13, 418-424. [CrossRef]

179. Lingera, P.; Müssigb, J.; Fischerb, H.; Koberta, J. Industrial hemp (Cannabis sativa L.) growing on heavy metal contaminated soil: Fibre quality and phytoremediation potential. Ind. Crop. Prod. 2002, 16, 33-42. [CrossRef]

180. Ingrao, C.; Lo Giudice, A.; Bacenetti, J.; Tricase, C.; Dotelli, G.; Fiala, M.; Siracusa, V.; Mbohwa, C. Energy and environmental assessment of industrial hemp for building applications: A review. Renew. Sustain. Energy Rev. 2015, 51, 29-42. [CrossRef]

181. Adesina, I.; Bhowmik, A.; Sharma, H.; Shahbazi, A. A Review on the Current State of Knowledge of Growing Conditions, Agronomic Soil Health Practices and Utilities of Hemp in the United States. Agriculture 2020, 10, 129. [CrossRef]

182. Montoya, Z.; Conroy, M.; Heuvel, B.D.; Pauli, C.S.; Park, S.H. Cannabis Contaminants Limit Pharmacological Use of Cannabidiol. Front. Pharmacol. 2020, 11, 571832. [CrossRef]

183. Gómez-Baggethun, E.; Barton, D.N. Classifying and valuing ecosystem services for urban planning. Ecol. Econ. 2013, 86, 235-245. [CrossRef]

184. Geron, C.D.; Guenther, A.B.; Pierce, T.E. An improved model for estimating emissions of volatile organic compounds from forests in the eastern United States. J. Geophys. Res. Atmos. 1994, 99, 12773-12791. [CrossRef]

185. Chaparro, L.; Terradas, J. Ecological Services of Urban Forest in Barcelona; Centre de Recerca Ecològica i Aplicacions Forestals (CREAF) Publisher, Universitat Autònoma de Barcelona: Barcelona, Spain, 2009.

186. Douglas, I. Urban ecology and urban ecosystems: Understanding the links to human health and well-being. Curr. Opin. Environ. Sustain. 2012, 4, 385-392. [CrossRef]

187. Seamans, G.S. Mainstreaming the environmental benefits of street trees. Urban For. Urban Green. 2013, 12, 2-11. [CrossRef]

188. Säumel, I.; Weber, F.; Kowarik, I. Toward livable and healthy urban streets: Roadside vegetation provides ecosystem services where people live and move. Environ. Sci. Policy 2016, 62, 24-33. [CrossRef]

189. Lyytimäki, J.; Petersen, L.K.; Normander, B.; Bezák, P. Nature as a nuisance? Ecosystem services and disservices to urban lifestyle. Environ. Sci. 2008, 5, 161-172. [CrossRef]

190. D'Amato, G. Urban air pollution and plant-derived respiratory allergy. Clin. Exp. Allergy 2000, 30, 628-636. [CrossRef]

191. Pataki, D.E.; Carreiro, M.M.; Cherrier, J.; Grulke, N.E.; Jennings, V.; Pincetl, S.; Pouyat, R.V.; Whitlow, T.H.; Zipperer, W.C. Coupling biogeochemical cycles in urban Environments: Ecosystem services, green solutions, and misconceptions. Front. Ecol. Environ. 2011, 9, 27-36. [CrossRef]

192. Arnold, E.; Strohbach, M.; Warrem, P. Pollution-Load Zones of Allergic Tree Pollen in Bosto, MA. In Proceedings of the Conference: Society for Urban Ecology (SURE), Berlin, Germany, 25 July 2013.

193. Bixler, R.D.; Floyd, M.F. Nature is scary, disgusting, and uncomfortable. Environ. Behav. 1997, 29, 443-467. [CrossRef]

194. Koskela, H.; Pain, R. Revisiting fear and place: Women's fear of attack and the built environment. Geoforum 2000, 31, 269-280. [CrossRef]

195. Šarapatka, B.; Miluse, A.; Cizkova, S.; Dotlacil, L.; Hluchy, M.; Kren, J.; Kuras, T.; Lastuvka, Z.; Lososova, Z.; Pokorny, E.; et al. Agroekologie: Východiska pro udržitelné zemědělské hospodaření. In Agroecology: Solutions for Sustainable Agriculture; Bioinstitut: Olomouc, Czech, 2010.

196. Escobedo, F.; Kroeger, T.; Wagner, J. Urban forests and pollution mitigation: Analyzing ecosystem services and disservices. Environ. Pollut. 2011, 159, 2078-2087. [CrossRef]

197. Galhena, D.H.; Freed, R.; Maredia, K.M. Home Gardens: A Promising Approach to Enhance Household Food Security and Wellbeing. Agric. Food Secur. 2013, 2, 1-13. [CrossRef]

198. Ellis, F.; Sumberg, J. Food production, urban areas and policy responses. World Dev. 1998, 26, 213-225. [CrossRef]

199. Cofie, O.; Kranjac-Berisavljevic, G.; Drechsel, P. The use of human waste for peri-urban agriculture in Northern Ghana. Renew. Agric. Food Syst. 2005, 20, 73-80. [CrossRef]

200. Scarano, A.; Chieppa, M.; Santino, A. Looking at flavonoid biodiversity in horticultural crops: A colored mine with nutritional benefits. Plants 2018, 7, 98. [CrossRef] [PubMed]

201. Scarano, A.; Chieppa, M.; Santino, A. Plant polyphenols-biofortified foods as a novel tool for the prevention of human gut diseases. Antioxidants 2020, 9, 1225. [CrossRef]

202. Sharma, A.; Katnoria, J.K.; Nagpal, A. Heavy metals in vegetables: Screening health risks involved in cultivation along wastewater drain and irrigating with wastewater. SpringerPlus 2016, 5, 488. [CrossRef]

203. Singh, K. Pollution and vegetable contamination: A review of the impact of various pollutants. Int. J. Sci. Eng. Technol. Res. 2016, $5,2314-2316$. 
204. Zhou, H.; Yang, W.-T.; Liu, L.; Gu, J.F.; Wang, W.-L.; Zou, J.-L.; Tian, T.; Peng, P.-Q.; Liao, B.-H. Accumulation of heavy metals in vegetable species planted in contaminated soils and the health risk assessment. Int. J. Environ. Res. Public Heath 2016, 13, 289. [CrossRef]

205. Matsuura, H.; Fett-Neto, A.G. Plant alkaloids: Main features, toxicity, and mechanisms of action. In Plant Toxins; Gopalakrishnakone, P., Carlini, C.R., Ligabue-Braun, R., Eds.; Springer: Dordrecht, The Netherlands, 2015; pp. 1-15. [CrossRef]

206. EFSA Panel on Contaminants in the Food Chain (CONTAM). Acute health risks related to the presence of cyanogenic glycosides in raw apricot kernels and products derived from raw apricot kernels. EFSA J. 2016, 14, 4424. [CrossRef]

207. Gleadow, R.M.; Møller, B.L. Cyanogenic glycosides: Synthesis, physiology, and phenotypic plasticity. Annu. Rev. Plant Biol. 2014, 65, 155-185. [CrossRef]

208. Zhang, X.; Shen, L.-Y.; Tam, V.W.Y.; Lee, W.W.Y. Barriers to implement extensive green roof systems: A Hong Kong study. Renew. Sustain. Energy Rev. 2012, 16, 314-319. [CrossRef]

209. Bryan, B.A.; Crossman, N.D. Impact of multiple interacting financial incentives on land use change and the 1982 supply of ecosystem services. Ecosyst. Serv. 2013, 4, 60-72. [CrossRef]

210. Porter, M.E.; Kramer, M.R. The Big Idea: Creating shared value. How to reinvent capitalism and unleash a wave of innovation and growth. Harv. Bus. Rev. 2011, 89, 62-77.

211. James, P.; Magee, L.; Scerri, A.; Steger, M.B. Urban Sustainability in Theory and Practice: Circles of Sustainability; Routledge: London, UK, 2015.

212. Folke, C.; Carpenter, S.R.; Walker, B.; Scheffer, M.; Chapin, T.; Rockstrom, J. Resilience thinking: Integrating resilience, adaptability and transformability. Ecol. Soc. 2010, 15, 20. [CrossRef]

213. Semeraro, T.; Radicchio, B.; Medagli, P.; Arzeni, S.; Turco, A. Integration of Ecosystem Services in Strategic Environmental Assessment of a Peri-Urban Development Plan. Sustainability 2021, 13, 122. [CrossRef] 